\title{
Kansas Antitrust Developments in the 21st Century: A Perspective from the Attorney General's Office
}

\author{
Derek Schmidt ${ }^{*}$ \& Lynette R. Bakker ${ }^{* *+}$
}

\section{INTRODUCTION}

Kansas has long been a leader in antitrust legislation. Stretching back to its early populist days, ${ }^{1}$ Kansas has legislated against antitrust and anticompetitive behavior since the 1890 s. $^{2}$ However, starting in the 1920 s and continuing until 2000, Kansas antitrust law development remained largely dormant with only occasional forays into statutory development. In 2000, the Governor's office, recognizing the out-of-date nature of Kansas antitrust statutes and responding to external pressures from citizens and businesses alike, proposed a wide-ranging amendment that synthesized numerous statutory provisions, officially creating the Kansas Restraint of Trade Act (KRTA) ${ }^{3}$ and modernizing Kansas antitrust law.

Then, in 2012, the Kansas Supreme Court rendered its decision in O'Brien v. Leegin Creative Leather Products, Inc. (O'Brien I). ${ }^{4}$ The court overruled the reasonableness standard that was established during the timeframe of the Kansas Fair Trade Act. ${ }^{5}$ In response to O'Brien I, Kansas

\footnotetext{
* Attorney General for the State of Kansas. Attorney General Schmidt is a graduate of the University of Kansas. He received his Master of Arts in International Politics from the University of Leicester in the United Kingdom, his Juris Doctor from Georgetown University Law Center, and his Doctor of Juridical Science from the University of Kansas School of Law.

** Assistant Attorney General, State of Kansas. We would like to thank Assistant Attorney General Christopher Teters and the staff of the Kansas Law Review for their comments and advice.

+ Although this article is coauthored, sections specifically pertaining to the work and experiences of Attorney General Schmidt will be written in the first person.

1. Populism, Kan. Historical SOC'Y: KAnSAPEDIA (Jan. 2020), https://www.kshs.org /kansapedia/populism/15160 [https://perma.cc/LR67-7TBV].

2. 2 aba Section of Antitrust law, State Antitrust Practice and Statutes 19-1 (Rocky C. Tsai et al. eds., 5th ed. 2014) [hereinafter StATE ANTITRUST PRACTICE].

3. KAN. STAT. ANN. §§ 50-158 to -163 (2000).

4. 277 P.3d 1062 (Kan. 2012).

5. Id. at 1083. "In 1937, Congress passed the Miller-Tydings Fair Trade Act ... which made vertical price restraints legal if authorized by a fair trade law enacted by a State." Leegin Creative Leather Prods., Inc. v. PSKS, Inc., 551 U.S. 877, 904-05 (2007). Kansas enacted its Fair Trade Act in 1937, which "specifically permitted contracts controlling resale prices . . . and explicitly authorized
} 
legislators filed several bills in the 2012 and 2013 legislative sessions, ${ }^{6}$ ultimately resulting in the 2013 KRTA amendments, which included revival of the reasonableness standard established during the Fair Trade Act period. ${ }^{7}$ This Article reviews the lead-up to and passage of the KRTA in 2000, efforts by litigators to utilize their newfound tools under the KRTA, and the legislative and judicial changes to the law following the KRTA's passage. Part II contains the narrative recollections of Kansas Attorney General Derek Schmidt's participation, as a staff member for the governor of Kansas, in the drafting and passage of the KRTA. Part III examines how the KRTA was utilized by government and private actors following the enactment of the KRTA. Part IV examines O'Brien I and the flurry of legislation following the decision. Part V discusses cases decided under the 2013 amendments to the KRTA. Finally, Part VI discusses the ongoing role of antitrust enforcement actions.

\section{THE RoAD TO THE KANSAS RESTRAint OF TRADE ACT: A NARRATIVE}

\section{"[T]he Governor is proposing to make our 19th Century antitrust laws relevant and useful in our 21 st Century economy. ",}

Kansas was the first state in the Union to enact a state-level antitrust law of general application. ${ }^{9}$ As one might expect, it dealt with agricultural issues, specifically grain and livestock sales. ${ }^{10}$ The statute has been amended infrequently, but twice in the past two decades. ${ }^{11}$ The statute was enacted in $1889,{ }^{12}$ right at the start of the populist era. ${ }^{13}$ In the $1890 \mathrm{~s}$, Kansas had two governors who were members of the Populist Party-the

private suits to punish deviation from them." O'Brien I, 277 P.3d at 1081. Suits could be brought against both resellers and third-party retailers who had not agreed to the price control. Id. "In 1958, [the Kansas Supreme Court] struck down the third-party provision as "statutory price-fixing by compulsion,' in conflict with the Kansas Constitution." Id. (citation omitted). The Kansas Legislature then repealed the entire Act in 1963. Id.

6. See Part IV.

7. Heckard v. Park, 188 P.2d 926, 931-32 (Kan. 1948), overruled by O'Brien I, 277 P.3d 1062; Okerberg v. Crable, 341 P.2d 966, 971 (Kan. 1959), overruled by O'Brien I, 277 P.3d 1062.

8. Hearing on H.B. 2855 Before the S. Judiciary Comm., 2000 Reg. Sess. 6 (Kan. 2000) [hereinafter Kansas Senate Hearing] (testimony of Derek Schmidt, Legislative Liaison and Special Counsel for the Office of the Governor, speaking in support of Kan. H.B. 2855 on Mar. 14, 2000).

9. State Antitrust PRACtice, supra note 2, at 19-1.

10. Id. at $19-1 \mathrm{n} .1$.

11. Id. at $19-2$.

12. Id. at $19-1$.

13. Populism, supra note 1. 
People's Party - and that was not coincidental. ${ }^{14}$ It was a time of suspicion of all things big intruding on the prior norms of the frontier mentality. ${ }^{15}$ That suspicion was reflected in public policy of the day, including the early antitrust laws. The Kansas antitrust laws were amended several times throughout the $1890 \mathrm{~s}^{16}$ and continued development into the trust-busting Teddy Roosevelt period of the early twentieth century. ${ }^{17}$ Then, no lasting substantive amendments to Kansas antitrust law occurred for almost eighty years. ${ }^{18}$

From 1923 to 2000, there was no single, principal antitrust act in Kansas. Instead, there was an eclectic collection of statutes that the revisor of statutes had codified in the same general area of the statutes: Chapter Fifty of the Kansas Statutes Annotated. ${ }^{19}$ However, the codification was not one seamless act.

During the 2000 regular session of the Kansas Legislature, I worked as Legislative Liaison and Special Counsel to Governor Bill Graves with a portfolio that included agriculture issues. During that time, I remember passions ran high in the state's livestock community as changing business practices and market dynamics disrupted this critical sector in the Kansas economy. ${ }^{20}$ Some Kansans felt that mergers and acquisitions, vertical integration of the production chain, and other business changes were beneficial to some livestock producers but detrimental to others. ${ }^{21}$ The

14. Id.; Lorenzo D. Lewelling, KAN. HistORICAL SOC'Y: KANSAPEDIA (Feb. 2017), https://www .kshs.org/kansapedia/lorenzo-d-lewelling/17109 [https://perma.cc/X8TP-GEMR]; John W. Leedy, KAN. HISTORICAL SOC'Y: KANSAPEDIA (Feb. 2017), https://www.kshs.org/kansapedia/john-wleedy/17110 [https://perma.cc/KVL2-DD35].

15. Populism, supra note 1 ("The group ... felt that the government's responsibility was to represent farmers rather than big business. In their view, railroads, banks, and other businesses received more support from government.").

16. State Antitrust Practice, supra note 2, at 19-1 to 19-2.

17. See Lewis L. Gould, The Presidency of Theodore Roosevelt $26-28,45-50$ (2d ed. 2011) (discussing President Roosevelt's trust busting and regulation).

18. The Kansas Fair Trade Act of 1937 and the Kansas Unfair Practices Act of 1941 were passed in this time frame, but both were declared unconstitutional and repealed. Neither Act has been replaced. See StATE ANTITRUST PRACTICE, supra note 2, at 19-4 n.25.

19. See Kan. Stat. AnN. ch. 50 (2000).

20. Lee Pitts, Blue Ribbons/Red Faces: Packer Control of NCBA, No-Bull Food News (Mar. 5, 2000), https://nobull.mikecallicrate.com/2000/03/05/blue-ribbonsred-faces-packer-control-of-ncba [https://perma.cc/D5GZ-XSHX].

21. Letter from Doran Junk, Exec. Dir., Kan. Cattlemen's Ass'n, to E. Clay Shaw, Chairman, House Subcomm. on Trade (Sept. 2, 2005), in WRITTEN COMMENTS ON TECHNICAL CORRECTIONS To U.S. TRAdE LAwS AND Miscellaneous Duty SuSPENSION BiLls 383 (2005) ("Established in 1998, the Kansas Cattlemen's Association represents independent, grass-root cattle producers and feedlot operators on marketing and trade issues. Prior to 1998, independent producers felt as though they were being both underrepresented and misrepresented by current organizations."); MARVIN Hayenga et al., Meat PaCKer Vertical InTEgration AND Contract Linkages in the BeeF AND PORK INDUSTRIES: AN ECONOMIC PERSPECTIVE 1 (May 22, 2000), 
passions of the time were reflected in numerous proposals for new legislation to regulate various sectors of the livestock marketplace, ${ }^{22}$ and the divisions ran deep within the state's agriculture community itself over the merits or demerits of these sorts of proposals.

At one point, the Governor asked my thoughts on various legislative proposals that were then-pending. I was fresh off a year as a Kansas Assistant Attorney General, where my duties included handling consumer protection and antitrust cases. I had formed two relevant opinions: First, the Kansas Consumer Protection Act, ${ }^{23}$ enacted in the 1970s and frequently amended and updated since, was a modern and wellfunctioning statute. Second, the various Kansas antitrust and related market-regulation laws, many enacted in the nineteenth century and not updated since 1923, were neither modern nor well-functioning. For example, at the time, both the Attorney General and every county attorney or district attorney in the state had the authority to bring an enforcement action. ${ }^{24}$ In fact, a Kansas statute made it a crime for local prosecutors not to bring an antitrust enforcement action. ${ }^{25}$ So I recommended to the Governor that, rather than layering on new statutes in response to current passions, perhaps a better approach would be to overhaul the statutes already on the books so they could function effectively.

The Governor said to make it so.

That was the origin of the 2000 amendments that resulted in what today is called the KRTA. ${ }^{26}$ I consulted a few key leaders in Kansas agriculture to advise them of the Governor's decision and to seek their general thoughts, but there was no bill drafting by group or committee.

http://econ2.econ.iastate.edu/faculty/hayenga/AMIfullreport.pdf [https://perma.cc/ZHR5-UU4Z] ("The livestock and meat industry's increasing use of production contract, marketing agreement, or ownership linkages between beef and pork producers and meat packers has provoked controversy and legislation to abolish many of these market linkages.").

22. See, e.g., S.B. 590, 72d Leg., 2000 Reg. Sess. (Kan. 2000) (proposing new regulations on the marketing of livestock). Other legislative proposals included replication of certain provisions of federal law, such as the Packers and Stockyards Act, and rewriting the Kansas antitrust law in an attempt to impose new standards of conduct for many large businesses operating in Kansas.

23. KAN. STAT. ANN. $\S \S 50-623$ to -643 (2013).

24. See id. §50-109 (1999) (amended 2000) ("It shall be the duty of the attorney general of the state and the county attorneys in their respective counties to diligently prosecute any and all persons violating any of the provisions of this act ....").

25. See Kansas Senate Hearing, supra note 8, at 3 (testimony of Derek Schmidt, Legislative Liaison and Special Counsel for the Office of the Governor, speaking in support of Kan. H.B. 2855 on Mar. 14, 2000) ("If the attorney general or any county attorney becomes aware of any violation of Kansas antitrust law but does not prosecute the violation, the prosecuting attorney forfeits his or her office and shall be fine $\$ 100$ to $\$ 1,000$. K.S.A. 50-109. If it is a county attorney who fails to prosecute, the county attorney may also face a jail sentence of at least ten (10) but not more than ninety (90) days. K.S.A. 50-118.”). K.S.A. § 50-109 was later amended to remove this language and K.S.A. § 50-118 was repealed in its entirety.

26. KAN. Stat. ANN. $\S \S 50-158$ to -163 . 
Over the course of about two weeks, I worked monk-like in my office up to my elbows in the statute books containing chapter fifty of the Kansas Statutes Annotated. I scoured article 1 of the chapter for provisions in antitrust and related statutes that seemed in need of deleting, supplementing, or modernizing. I also searched the Kansas Consumer Protection Act with an eye toward enforcement tools and other provisions that seemed suitable to import into antitrust statutes.

The result was Kansas House Bill 2855, which was introduced at the Governor's request on February 3, 2000. ${ }^{27}$ The proposal's overall purpose was to "revise, update and strengthen the antitrust provisions that currently are part of Kansas law" in order "to make our 19th Century antitrust laws relevant and useful in our twenty-first century economy." 28 We considered the bill a "proper, balanced approach" to the "modernization of Kansas antitrust law." 29 Its key elements included:

- "Give[] the [A]ttorney [G]eneral modern investigative powers, including administrative subpoena power . . .."30

- "Allow[] [c]ourts to impose a [uniform] civil penalty up to $\$ 5,000.00$ for each day a violation . . occurs," replacing various and eclectic penalties scattered throughout the law. ${ }^{31}$

- "Create[] explicit authority for the Attorney General to recover the state's investigation costs in successful litigation." 32

- "Give[] the [A]ttorney [G]eneral and the [c]ourt a 'menu' of [options] available for tailoring an appropriate remedy after liability is found," replacing various section-specific remedies, some of which (such as forfeiture of corporate charter) purported to be mandatory in certain circumstances. ${ }^{33}$

- "Permit[] Kansas courts to exercise jurisdiction over nonresident entities that violate th[e] statute to the maximum extent allowed by the United States Constitution." 34

- "Concentrate[] all public enforcement power in the [A]ttorney

27. H.B. 2855, 78th Leg., 2000 Reg. Sess. (Kan. 2000); H. JournAL, 78th Leg., 2000 Reg. Sess. (Kan. 2000) (discussing Kan. H.B. 2855).

28. Hearing on H.B. 2855 Before the H. Judiciary Comm., 2000 Reg. Sess. 1 (Kan. 2000) (testimony of Derek Schmidt, Legislative Liaison and Special Counsel for the Office of the Governor, speaking in support of H.B. 2855 on February 17, 2000).

29. Kansas Senate Hearing, supra note 8, at 6 (testimony of Derek Schmidt, Legislative Liaison and Special Counsel for the Office of the Governor, speaking in support of Kan. H.B. 2855 on Mar. 14, 2000).

30. Id. at 4-5.

31. Id.

32. Id.

33. $I d$.

34. Id. 
[G]eneral rather than in county and district attorneys." 35

- "Permit[] enforcement actions to be filed in Shawnee County District Court." 36

- "Consolidate[] the "hodgepodge" provisions of current law, as set forth in Article 1 of Chapter 50, into a single statute called the Kansas Restraint of Trade Act. This consolidation makes clear that all state antitrust actions are governed by a uniform set of procedural rules, one set of available remedies, and one uniform set of investigative powers." ${ }^{37}$

- "Make[] the entire statute civil and repeal the miscellaneous criminal penalties in the current law."

- "Put[] all enforcement litigation under the Code of Civil Procedure," rather than the collection of ad hoc procedures scattered throughout the law. ${ }^{39}$

- "Repeal[] more than thirty (30) outdated and unused sections of law," which included throwbacks to the populist era imposing mandatory fines, jail time and forfeiture of office on law enforcement officers, prosecutors and other public officials who fail to enforce the antitrust laws. ${ }^{40}$

- "Require[] the [A]ttorney [G]eneral to report annually on her antitrust investigations and enforcement activities . ..."41

- Make the definition of "person" covered by the law uniform throughout the statute. ${ }^{42}$

Both the House and Senate were interested in adding a provision to extend authority for the Attorney General to review and investigate mergers and acquisitions, although the two chambers took different approaches. ${ }^{43}$ A compromise was reached, ${ }^{44}$ and with that further change,

35. Id.

36. Id.

37. Id.

38. Id.

39. Id.

40. Id.

41. Id.

42. Id.

43. H.B. 2855, 78th Leg., 2000 Reg. Sess. (Kan. 2000); S. JOURNAL, 78th Leg., 2000 Reg. Sess. (Kan. 2000). The House passed H.B. 2855 with amendment proposed by the House Judiciary Committee. The Senate added additional changes to the bill. The House non-concurred with the amendments, but ultimately acceded to the Senate amendments and the conference committee agreed to further amendments.

44. This compromise is codified at KAN. STAT. ANN. $§ 50-162$ (2013). 
the legislation passed unanimously. ${ }^{45}$ On May 5, 2000, the Governor signed the bill into law.

Perhaps not surprisingly, there was great interest among the practitioner community in what we had just done. I'm sure we did a few things that, in hindsight, had unintended consequences. But, since then, we've seen quite a bit of evolution in how antitrust enforcement is dealt with in Kansas - perhaps because of the new statute or maybe just because of changed times.

\section{UTILIZING THE NEW TOOLS OF THE KRTA}

Under Kansas law, two sets of players enforce the KRTA. First, the Kansas Attorney General was granted exclusive authority by the KRTA to bring a public enforcement action on behalf of the State. ${ }^{46}$ Second, individuals can bring private causes of action. ${ }^{47}$ This Part examines both public actions, brought by the Office of the Kansas Attorney General, and private actions brought since the enactment of the KRTA.

\section{A. Attorney General Enforcement: 2000-2013}

Since the KRTA became law, the Office of the Kansas Attorney General has been involved in numerous antitrust matters. Even the authors of this Article were surprised to learn the number of lawsuits and settlements that the Attorney General has handled; thus, only a handful will be discussed in depth. The remaining cases will be briefly mentioned whenever relevant.

The majority of matters investigated and enforced by the Attorney General settle, whether litigation was filed or not. This can likely be attributed to the grant of prelitigation investigatory authority by the KRTA. $^{48}$ This authority allows the Attorney General to thoroughly investigate a matter prior to filing litigation or approaching a noncompliant entity with a settlement offer.

Due to the typically large scope of an antitrust case and investigation - as well as the large-scale effect of anticompetitive conduct by a nationwide or regional company-the Attorney General pursues

\footnotetext{
45. In the Senate, the legislation passed 40-0. S. JournaL, 78th Leg., 2000 Reg. Sess. (Kan. 2000). In the House, the vote was 124-0. H. JournAL, 78th Leg., 2000 Reg. Sess. (Kan. 2000).

46. KAN. StAT. ANN. $\S 50-162$. As discussed above, prior to 2000, the Attorney General and every county attorney or district attorney in the state had the authority to bring an enforcement action. See supra note 23 and accompanying text.

47. Kan. Stat. ANN. § 50-161.

48. Id. $\S \S 50-153,-159$ (2000).
} 
antitrust matters almost exclusively in a multistate capacity. ${ }^{49}$ Nothing prohibits the Attorney General from taking action solely on behalf of Kansas. However, unless a company operates exclusively in Kansas or the impact is only felt in Kansas, a group of states will generally wish to pursue an antitrust matter. By pooling resources together, a group of states can more effectively pursue large companies for their anti-competitive behavior. For the same reason, the states frequently, but not always, will coordinate investigations, lawsuits, and settlements with federal agencies as well.

The Attorney General filed and/or settled twenty antitrust matters between 2000 and 2013-with the products or services varying from women's shoes to beef to pharmaceuticals and health care products. ${ }^{50}$ The

49. See sources cited infra note 50 .

50. See Civil Litigation Detail: Florida v. Nine West Group, Inc., No. 7:00-CV-01707 (S.D.N.Y. 2000), Antitrust Multistate Litig. DAtABASE, http://app3.naag.org/antitrust/search/viewCivil Litigation.php?trans_id=173 [https://perma.cc/7K2C-JNFY] (last visited Apr. 12, 2020) [hereinafter Nine West Settlement] (out-of-court settlement entered in 2000 regarding women's shoes); In re Lorazepam \& Clorazepate Antitrust Litig., 205 F.R.D. 369 (D.D.C. 2002) (pharmaceutical drugs); New York v. Salton, Inc., 265 F. Supp. 2d 310 (S.D.N.Y. 2003) (appliances); Civil Litigation Detail: In re Buspirone Antitrust Litig., No. $01-c v-11401$ (S.D.N.Y. 2001), ANTITRUST Multistate LiTIG. DATABASE, http://app3.naag.org/antitrust/search/viewCivilLitigation.php?trans_id=190\&KT_back $=1$ [https://perma.cc/XWC6-99S7] (last visited Apr. 12, 2020) [hereinafter In re Buspirone Settlements] (settlement entered on March 7, 2003 regarding pharmaceutical drug Buspar and letter agreement settlement of contempt claims entered on December 22, 2008); In re Cardizem CD Antitrust Litig., 218 F.R.D. 508, 538 (E.D. Mich. 2003) (pharmaceutical drugs); In re Compact Disc Minimum Advertised Price Antitrust Litig., 216 F.R.D. 197 (D. Me. 2003) (CDs); Ohio v. Bristol-Myers Squibb Co., No. 1:02-cv-01080, 2003 WL 21105104, at *4 (D.D.C. May 13, 2003) (pharmaceutical drugsTaxol); Ohio v. Hearst Trust, No. 1:05-cv-00384 (D.D.C. Feb. 25, 2005) (electronic databases); In re Terazosin Hydrochloride Antitrust Litig., No. 99MDL1317, 2005 WL 2451960 (S.D. Fla. July 8, 2005) (pharmaceutical drugs); In re Relafen Antitrust Litigation, 221 F.R.D. 260 (D. Mass. 2004) (pharmaceutical drugs); In re Remeron End-Payor Antitrust Litig., No. 02-2007, 2005 WL 2230314 (D.N.J. Sept. 13, 2005) (pharmaceutical drugs); Civil Litigation Detail: In the Matter of GlaxoSmithKline, PLC (Augmentin), ANTITRUST MultistATE LiTIG. DATABASE, http://app3.naag .org/antitrust/search/viewCivilLitigation.php?trans_id=458\&KT_back=1 [https://perma.cc/7DY3 -WNJR] (last visited Apr. 12, 2020) [hereinafter GlaxoSmithKliné Settlement] (out-of-court settlement entered in 2006 regarding pharmaceutical drug Augmentin); Civil Litigation Detail: Maryland $v$. SmithKline Beecham Corp., No. 2:06-cv-02398-JP (E.D. Pa. Mar. 27, 2006), ANTITRUST MultistATE LiTIG. DATABASE, http://app3.naag.org/antitrust/search/viewCivilLitigation.php?trans id=408\&KT back=1 [https://perma.cc/73FK-3PD4] (last visited Apr. 12, 2020) [hereinafter SmithKline Beecham Settlement] (settlement entered in 2006 regarding pharmaceutical drug Paxil); Civil Litigation Detail: Colorado v. Warner Chilcott, No. 1:05-cv-02182 (D.D.C. 2005), ANTITRUST MultistATE LiTIG. DATABASE, http://app3.naag.org/antitrust/search/viewCivilLitigation.php?trans _id=527\&KT_back=1 [https://perma.cc/GV4F-NTJE] (last visited Apr. 12, 2020) [hereinafter Warner Chilcott Settlement] (settlement entered in 2006 regarding pharmaceutical drugs-Ovcon); United States v. JBS S.A., No. 108CV05992, 2008 WL 5560009 (N.D. Ill. Nov. 7, 2008) (beef packing industry); Civil Litigation Detail: United States v. Verizon Commc'ns Inc., No. 08-cv-01878 (D.D.C. 2008), AnTITRUST Multistate LitiG. DATABASE, http://app3.naag.org/antitrust/search/viewCivil Litigation.php?trans_id=612\&KT_back=1 [https://perma.cc/4QHV-2FRV] (last visited Apr. 12, 2020) [hereinafter Verizon Settlement] (settlement reached in 2008 regarding telecommunication services); Civil Litigation Detail: Richardson v. Akzo Nobel (In re Vitamins Antitrust Litig.), No. 1:09- 
types of conduct ranged from price fixing to anticompetitive mergers. Areas of antitrust enforcement change based on what anticompetitive enforcement actually occurs, as well as what comes to the attention of regulators and prosecutors. There were a number of matters filed prior to 2000 that were resolved after 2000, but for the sake of this review, we will only discuss matters that were brought in 2000 or later.

Matters brought during this timeframe can be divided into four major categories: pharmaceutical drugs and medical products, consumer goods, merger challenges, and government and nonprofit investments. We will briefly highlight each of these areas.

\section{Pharmaceutical Drugs and Medical Products}

Many of the cases brought by the Attorney General in the twenty-first century involved pharmaceutical drugs. ${ }^{51}$ The reasons are multifaceted, but generally, anticompetitive activity in the pharmaceutical arena adversely affects a large portion of the Kansas population-as well as many Kansas governmental agencies, including Medicaid. ${ }^{52}$ For this reason, matters involving pharmaceutical drugs are more likely to come to the Attorney General's attention, from both consumer complaints and information received from other governmental entities. These matters affect the population in such a way that the Attorney General feels compelled to address the matter through litigation or settlement. Additionally, anticompetitive activity in the pharmaceutical drug market tends to cause significant monetary damages that can be recovered for the state and its citizens. Eleven of the Attorney General's enforcement actions during this initial timeframe were related to pharmaceutical products. $^{53}$ The drugs at issue treated a variety of conditions, including,

cv-02112-TFH (D.D.C. 2009), Antitrust Multistate Litig. Database, http://app3.naag.org /antitrust/search/viewCivilLitigation.php?trans_id $=575 \&$ KT_back $=1 \% 20 \quad[$ https://perma.cc/JK4R -2J8T] (last visited Apr. 12, 2020) [hereinafter In re Vitamins II Settlement] (settlement entered in 2009 regarding vitamin supplements); Florida v. Abbott Labs., No. 08-155, 2010 WL 171692 (D. Del. Jan. 8, 2010) (pharmaceutical drugs); Texas v. Penguin Grp. (USA) Inc., No. 1:12-cv-03394 (S.D.N.Y. filed Apr. 30, 2012) (ebooks); see also infra Section III.A.4 (municipal bonds settlements).

51. In re Lorazepam \& Clorazepate Antitrust Litig., 205 F.R.D. at 369; In re Buspirone Settlements, supra note 50; In re Cardizem CD Antitrust Litig., 218 F.R.D. at 538; Bristol-Myers Squibb Co., 2003 WL 21105104, at *4; In re Terazosin Hydrochloride Antitrust Litig., 2005 WL 2451960; In re Relafen Antitrust Litig., 221 F.R.D. at 260; In re Remeron End-Payor Antitrust Litig., 2005 WL 2230314; GlaxoSmithKline Settlement, supra note 50; SmithKline Beecham Settlement, supra note 50; Warner Chilcott Settlement, supra note 50; Abbott Labs., 2010 WL 171692.

52. PATRicia M. DANZON, Wharton SCh., UniV. OF PA., COMPETITION AND ANTITRUST ISSUES IN THE PHARMACEUTICAL INDUSTRY 33 (2014) ("Claims of monopolization are frequently joined by states attorneys general, claiming compensation for excessive costs to Medicaid and other state programs.").

53. See cases cited supra note 51. 
inter alia, high blood pressure, seizures, sleeping disorders, anxiety, cancer, arthritis, depression, and high cholesterol. ${ }^{54}$ The number of states involved in these matters varied from just three to all fifty. ${ }^{55}$

The majority of the pharmaceutical drug actions brought by the Attorney General dealt with a generic drug's delayed entry into the market - typically, a "pay-for-delay" allegation. ${ }^{56}$ "Pay-for-delay" occurs when a branded manufacturer pays a generic drug company (or companies) not to bring lower-cost alternatives to market. ${ }^{57}$ The Federal Trade Commission (FTC) has reported that "pay-for-delay" agreements "cost consumers and taxpayers $\$ 3.5$ billion in higher drug costs every year." patent litigation, and other fraudulent patent activity. ${ }^{59}$ Every pharmaceutical drug matter pursued by the Attorney General between 2000 and 2013 resulted in a settlement with the drug manufacturers.

The one outlier medical case that did not involve pharmaceutical drugs was a case involving electronic drug information databases. ${ }^{60}$ The matter started when First Data Bank acquired its competitor, Medi-Span, Inc. ${ }^{61}$ The FTC investigated and determined that the combination gave First Data Bank an illegal monopoly. ${ }^{62}$ That investigation resulted in a settlement on behalf of nongovernmental consumers that included the divestiture of Medi-Span, Inc. ${ }^{63}$ The states subsequently investigated and reached a settlement to recover damages suffered by state governmental purchasers. $^{64}$

\footnotetext{
54. Id.

55. Id.

56. See, e.g., In re Remeron End-Payor Antitrust Litig., No. 02-2007, 2005 WL 2230314, at *1 (D.N.J. Sept. 13, 2005) ("The Complaint alleges ... that Defendants ... improperly delayed the listing of [their] patent in the Orange Book to prolong their monopoly ....").

57. Pay-for-Delay: When Drug Companies Agree Not to Compete, FeD. Trade Comm'N, https:// www.ftc.gov/news-events/media-resources/mergers-competition/pay-delay [https://perma.cc/Z8TZ $-8 \mathrm{KXK}]$ (last visited Apr. 12, 2020).

58. Id.

59. See Monopolization Defined, FED. TRADE COMM'N, https://www.ftc.gov/tips-advice /competition-guidance/guide-antitrust-laws/single-firm-conduct/monopolization-defined [https:// perma.cc/P4B5-HS5U] (last visited Apr. 12, 2020); Saami Zain, Antitrust Liability for Maintaining Baseless Litigation, 54 SANTA ClarA L. REV. 729, 730 (2014) (discussing the "injury caused by anticompetitive sham litigation"); see also cases cited supra note 51.

60. See Complaint at 1, Ohio v. Hearst Trust, No. 1:05-CV-00384 (D.D.C. Feb. 25, 2004), 2005 WL 696707.

61. Id.

62. Id. at $4-5$.

63. Id. at 5 .

64. See Joint Notice of Filing, Ohio v. Hearst Trust, No. 1:05CV00384 (D.D.C. Mar. 2, 2005) (providing notice that the parties jointly filed a settlement agreement).
} 


\section{Consumer Goods}

The Attorney General brought actions regarding consumer goods in five matters between 2000 and 2013. The products involved were women's shoes, ${ }^{65}$ George Foreman grills, ${ }^{66}$ compact discs, ${ }^{67}$ vitamin supplements, ${ }^{68}$ and eBooks. ${ }^{69}$ Three of the matters involved minimum resale price fixing or minimum advertised price policies. ${ }^{70}$ Each of these require a retailer to advertise and/or sell products at a specific price. ${ }^{71}$ Failure to comply with the policy could result in a manufacturer refusing to supply the product to the retailer or otherwise punishing noncompliance. The legal standard in this area has changed and such policies are no longer considered to be violations of the law unless they are found to be unreasonable restrictions on competition. ${ }^{72}$ Several of the cases also involved agreements for exclusive dealing, agreements to prohibit sales of competitor products, or agreements to increase the price of a product to comply with a pricing policy. ${ }^{73}$

The fourth matter, or more appropriately, matters, were the In re Vitamins Antitrust Litigation cases. There were two separate cases filed. The first case (Vitamins I) was filed prior to 2000 in $1999 .{ }^{74}$ Vitamins I addressed both consumer and commercial vitamin supplements, including consumer and animal food products. Vitamins II was related to the first litigation, but with different defendants. ${ }^{75}$ Both matters involved allegations of price fixing.

Vitamins $I^{76}$ was particularly interesting because it followed criminal

65. Nine West Settlement, supra note 50.

66. New York v. Salton, Inc., 265 F. Supp. 2d 310, 312 (S.D.N.Y. 2003).

67. In re Compact Disc Minimum Advertised Price Antitrust Litig., 216 F.R.D. 197, 200 (D. Me. 2003).

68. In re Vitamins II Settlement, supra note 50.

69. United States v. Apple, Inc., 952 F. Supp. 2d 638, 645 (S.D.N.Y. 2013), aff'd, 791 F.3d 290 (2d Cir. June 30, 2015).

70. See Salton, Inc., 265 F. Supp. 2d at 312; In re Compact Disc, 216 F.R.D. at 200; Apple, Inc., 952 F. Supp. 2d at 647.

71. Manufacturer-Imposed Requirements, FED. TRADE COMM'N, https:/www.ftc.gov /tips-advice/competition-guidance/guide-antitrust-laws/dealings-supply-chain/manufacturer-imposed [https://perma.cc/3PAZ-3W4X] (last visited Apr. 12, 2020).

72. See generally id.

73. See, e.g., Salton, Inc., 265 F. Supp. 2d at 312 (dealing with exclusive dealing agreements and prohibiting sales of competitor products); Apple, Inc., 952 F. Supp. 2d at 647 (alleging an agreement to increase the price of a product to comply with a pricing policy).

74. Civil Litigation Detail: New York v. Hoffmann-LaRoche, Inc. (In re Vitamins I), No. 99.010358 (D.D.C. 1999), ANTITRUST MultistATE LiTIG. DATABASE, http://app3.naag.org/antitrust /search/viewCivilLitigation.php?trans_id=182\&KT_back=1 [https://perma.cc/KRP6-DFSK] (last visited Apr. 12, 2020) [hereinafter In re Vitamins I Settlement].

75. In re Vitamins II Settlement, supra note 50.

76. In re Vitamins I Settlement, supra note 74. 
guilty pleas obtained by the U.S. Department of Justice (DOJ), ${ }^{77}$ it included heavy involvement of private parties, ${ }^{78}$ and it resulted in a Master Settlement Agreement ${ }^{79}$ with the States, the private parties, and the defendants. The settlement agreement was then implemented in state court. ${ }^{80}$ Vitamins II was filed jointly by States and private parties against the second group of defendants in the District of Columbia. ${ }^{81}$ The Vitamins II case was resolved by a multistate settlement agreement, ${ }^{82}$ similar to the original master settlement of the first case. However, in the second settlement, the States only took responsibility for distribution of the consumer portion of the fund, and not the commercial claimant funds. The States were tasked with distributing the consumer settlement fund to government entities, not for profit enterprises, and/or charitable organizations "for the improvement of the health and/or nutrition of the citizens of that State and/or the advancement of nutritional, dietary or agricultural science. $"{ }^{\circ 3}$

All of these consumer goods matters were resolved by settlements with the defendants, which included cy pres relief. In many consumer goods cases, there is no practical way to identify the affected consumers or to verify the consumer purchase. For example, how many consumers hang on to their receipts for a pair of shoes or vitamin enriched bread for years? Thus, much of the money recovered in these matters was distributed to not-for-profits and other Kansas entities.

A fifth consumer goods matter involving eBooks was filed in 2012 against Apple and five major publishers. ${ }^{84}$ The majority of this case was litigated post-2013, so it will be discussed in Part V.

77. Plea Agreement, United States v. F. Hoffmann-La Roche Ltd., No. 99-CR-184-R (N.D. Tex. May 20, 1999), https://www.justice.gov/sites/default/files/atr/legacy/2006/04/10/hoffman.pdf [https:// perma.cc/7D87-Y7JV].

78. Todd v. F. Hoffmann-La Roche Ltd. (In re Kan. Vitamins Antitrust Litig.), No. 98-C-4574 (Dist. Ct. Wyandotte Cty. Oct. 1, 1998).

79. Master Settlement Agreement, New York v. Hoffmann-La Roche, Inc. (In re Vitamins Antitrust Litig.), No. 1:09-CV-02112 (Oct. 10, 2000), http://app3.naag.org/antitrust/docs/182 .civil.NY\%20v.\%20Hoffmann\%20LaRoche\%20(vitamins).pdf [https://perma.cc/8R7N-66RH] (amended Jan. 22, 2001).

80. Todd v. F. Hoffman-La Roche Ltd. (In re Kan. Vitamins Antitrust Litig.), No. 98-C-4574 (Dist. Ct. Wyandotte Cty. Apr. 3, 2002).

81. In re Vitamins II Settlement, supra note 50.

82. Vitamins Antitrust Litigation Multistate Settlement Agreement, Richardson v. Akzo Nobel (In re Vitamins Antitrust Litig.), No. 1:09-cv-02112 (D.D.C. Oct. 30, 2009), http://app3.naag.org /antitrust/docs/575.civil.2009\%20Vitamins\%20Settlement\%20Agreement.pdf [https://perma.cc 1373L-93QR].

83. Id. at 27.

84. Texas v. Penguin Grp. (USA) Inc., No. 1:12-cv-03394 (S.D.N.Y. filed Apr. 30, 2012). 


\section{Merger Challenges}

The Attorney General opposed two mergers between the enactment of the KRTA and the 2013 amendments. The industries at issue were beef packing $^{85}$ and telecommunications. ${ }^{86}$ Although the Attorney General reviews many mergers for potential action, only a few are actually challenged. This is both a matter of resources and state interest. To make a decision to challenge a merger, there must be a significant reason to invest the time and effort into the case. It must be of importance to Kansas specifically. All large mergers are reviewed by federal agencies for anticompetitive effects ${ }^{87}$ and typically the action undertaken (or not taken) by the federal agency is determined to be the best course of action for Kansas. However, when a merger uniquely affects the citizens or economy of Kansas, as in these two merger challenges, the Attorney General can choose to file suit or take other action to challenge a merger felt to harm Kansas.

As indicated by the previous discussion of the 2000 amendments to the antitrust code, the beef industry is of great importance to the State of Kansas. ${ }^{88}$ In 2008, JBS S.A., the world's largest beef packer, ${ }^{89}$ announced plans to acquire the fourth largest beef packer in the United StatesNational Beef Packing. ${ }^{90}$ JBS had just completed two other beef packer acquisitions immediately prior. ${ }^{91}$ National Beef Packing operated two plants in Kansas - one in Liberal and one in Dodge City - as well as a plant in California. ${ }^{92}$ Kansas had particular concern about the merger because of the industry involved and the plant locations in the State. ${ }^{93}$ The

85. Complaint at 2, United States v. JBS S.A., No. 1:08-CV-05992 (N.D. Ill. Oct. 20, 2008), 2008 WL 4919390 .

86. Complaint at 2, United States v. Verizon Commc'ns Inc., No. 1:08-cv-993-EGS (D.D.C. Apr. 24, 2009), 2009 WL 1380165.

87. Merger Review, FED. TRADE COMM'N, https://www.ftc.gov/news-events/media-resources /mergers-and-competition/merger-review [https://perma.cc/C9DL-Q6MA] (last visited Apr. 12, 2020).

88. See supra Part II; see also KAN. DeP’T OF AGRIC., BeEF 2 (2019) (“[B]eef cattle farming and ranching has a direct output of approximately $\$ 6.3$ billion and employs nearly 34,130 Kansans.").

89. Complaint, United States v. JBS S.A., supra note 85, at 2; Emilene Ostlind, The Big Four Meatpackers, HIGH COUNTRY NEwS (Mar. 21, 2011), https://www.hcn.org/issues/43.5/cattlemen -struggle-against-giant-meatpackers-and-economic-squeezes/the-big-four-meatpackers- $\quad$ [https:// perma.cc/UQR4-WN3C].

90. Complaint, United States v. JBS S.A., supra note 85, at 2.

91. Id. at 3 .

92. Id. at 5 .

93. Id. at 6 ("National's plants in ... Kansas are among the largest and most profitable beef packing plants in the nation."). 
Attorney General, with twelve other states and the DOJ, ${ }^{94}$ sued to block the merger in October of 2008, alleging the merger "would eliminate headto-head competition" between the companies, diminish competition in the market for the purchase of fed cattle and USDA-graded boxed beef, and adversely affect prices cattle producers and ranchers received for their cattle, as well as prices consumers paid for beef. ${ }^{95}$ After several months in litigation, the parties abandoned the merger and the case was dismissed. ${ }^{96}$

The second merger challenge involved Verizon's acquisition of Alltel in 2008. ${ }^{97}$ The Attorney General, with six other states and the DOJ, filed suit alleging the merger of Verizon and Alltel would lessen competition in interstate trade and commerce for mobile wireless telecommunications services in certain U.S. cellular market areas resulting in higher prices and lower quality of service for cellular users. ${ }^{98}$ This was another case where specific Kansas markets were particularly affected and the Attorney General felt it was important to file suit. Seven rural service area cellular market areas in Kansas were affected by the transaction. ${ }^{99}$ The defendants ultimately agreed to a settlement that included the divestiture of the affected cellular market areas to preserve competition. ${ }^{100}$

In a third merger addressed during this timeframe, the Attorney General filed comments in the Federal Communications Commission (FCC) review, expressing antitrust concerns regarding the proposed merger between AT\&T, Inc. and T-Mobile USA and asking that the FCC take necessary action to deny the proposed merger. ${ }^{101}$ The proposed merger required both the FCC and the DOJ approval to proceed. The DOJ

94. Civil Litigation Detail: United States v. JBA S.A., No. 1:08-CV-05992 (N.D. Ill. 2008), ANTITRUST MULTISTATE Litig. DATABASE, http://app3.naag.org/antitrust/search/viewCivilLitigation .php?trans_id=547\&KT_back=1 [https://perma.cc/93N2-REFY].

95. Complaint, United States v. JBS S.A., supra note 85, at 3-4.

96. Stipulation of Dismissal, United States v. JBS S.A., No. 1:08-CV-05992 (N.D. Ill. Feb. 26, 2009).

97. Complaint at 2, United States v. Verizon Commc'ns Inc., No. 1:08-cv-993 (D.D.C. Oct. 30, 2008), 2009 WL 1380165.

98. Id. at 3 .

99. Id. at 8-9, 19-20.

100. Press Release, U.S. Dep't of Justice, Justice Department Requires Divestitures in Verizon's Acquisition of Alltel (Oct. 30, 2008), https://www.justice.gov/archive/atr/public/press_releases/2008 /238941.htm [https://perma.cc/75K7-JJGK].

101. See AT\&T - T-Mobile: Communications from Government Officials, FED. COMMC'NS COMM'N, https://www.fcc.gov/att-t-mobile-communications-government-officials [https://perma.cc /Y9QF-DDV6] (last visited Apr. 12, 2020) (listing filed communications regarding the merger, including two letters "filed by State Attorney General Derek Schmidt, Kansas" on Nov. 21, 2011); see also Brendan Sasso, Kansas Attorney General Urges FCC to Kill AT\&T/T-Mobile Deal, THE HILL (Nov. 22, 2011, 7:24 PM), https://thehill.com/policy/technology/195147-kansas-attorney-general -urges-fcc-to-kill-atat-t-mobile-deal [https://perma.cc/P2AV-SEG3]. 
brought a lawsuit, joined by seven other states, to block the proposed merger. ${ }^{102}$ Although some states joined the DOJ suit, the Attorney General felt that, in this case, comments were the most appropriate method of expressing the concerns about the merger. On November 23, 2011, AT\&T withdrew its merger application, which the FCC allowed. ${ }^{103}$ At the same time, the FCC released Staff Analysis and Findings, which indicated the merger would harm competition in the wireless service industry. ${ }^{104}$ On December 19, 2011, AT\&T announced it was abandoning its bid to acquire T-Mobile. ${ }^{105}$

\section{Government and Nonprofit Investments}

The Attorney General entered into settlements with five financial institutions and one broker related to anticompetitive conduct in the municipal bond derivative investment market between 2010 and 2011. ${ }^{106}$ A group of states investigated anticompetitive activities in the municipal bond derivatives industry regarding a nationwide scheme to rig bids and engage in other anticompetitive conduct that defrauded state agencies, municipalities, school districts and not-for-profit entities in their purchase of municipal bond investments. ${ }^{107}$ These government and nonprofit organizations issue bonds and reinvest the proceeds until the funds are needed or enter into contracts to hedge interest rate risk on bonds. ${ }^{108}$ The States' investigation revealed fraudulent and conspiratorial conduct

102. Complaint, United States v. AT\&T Inc., No. 1:17-cv-02511 (D.D.C. Nov. 20, 2017), 2017 WL 5564815 .

103. Tiffany Hsu \& Jim Puzzanghera, AT\&T Withdraws T-Mobile Merger Plan From FCC, L.A. TiMES (Nov. 25, 2011, 12:00 AM), https://www.latimes.com/business/la-xpm-2011-nov-25-la-fi-att -merger-setback-20111125-story.html [https://perma.cc/NR3G-5ST3].

104. Fed. COMMC'NS COMM'N, StAFF ANALYSIS AND FINDINGS, WT DOCKET No. 11-65, at 111 (Nov. 29, 2011), https://docs.fcc.gov/public/attachments/DA-11-1955A2.pdf ("[T] he staff concludes that significant harms to competition are likely to result, primarily in the form of increased prices for consumers, reduced incentives for innovation, and decreased consumer choice.").

105. Michael J. De La Merced, AT\&T Ends \$39 Billion Bid for T-Mobile, N.Y. TiMES: DEALBoOK (Dec. 19, 2011，4:44 PM), https://dealbook.nytimes.com/2011/12/19/att-withdraws-39-bid-for -t-mobile [https://perma.cc/DYS9-FJLP].

106. Press Release, Derek Schmidt, Kan. Att'y Gen., Municipal Bond Settlements Return Money to State, Local Entities (Dec. 28, 2011), https://www.ag.ks.gov/media-center/news-releases/2011 -news-releases/2011/12/28/attorney-general-schmidt-municipal-bond-settlements-return-money-tostate-local-entities [https://perma.cc/VCE8-KCED] [hereinafter Press Release, Municipal Bond Settlements] ("Six settlements have been reached since the start of this investigation, including five this year.").

107. Id.; see also DereK SChMidt, KAn. AtT'y Gen., CONSUMER PROTECTION Division, 2011 ANNUAL REPORT 12 (2012), https://ag.ks.gov/docs/documents/2011-consumer-protection-annual -report.pdf?sfvrsn=7338c8bd_4 [https://perma.cc/BPZ3-6EM5] (detailing the scope of the alleged misconduct).

108. Press Release, Municipal Bond Settlements, supra note 106. 
between individuals at the "financial institutions and certain brokers with whom they had working relationships."109 Such wrongful conduct "deprived bond issuers of a competitive, transparent marketplace." 110 As a result of this conduct and its effect on the marketplace, "states, local governments and not-for-profit entities entered into municipal derivatives contracts on less advantageous terms than they would have otherwise, thereby adding costs to taxpayers."111 Identified state governmental and not-for-profit organizations affected by the conduct received restitution payments from the settlements. ${ }^{12}$

\section{B. Notable Private Actions: 2000-2013}

Many private causes of action that address Kansas antitrust law have been filed since 2000 in both state and federal court. ${ }^{113}$ We have limited our discussion to cases brought before the Kansas Supreme Court, the Kansas Court of Appeals, the U.S. Supreme Court, the U.S. Court of Appeals for the Tenth Circuit, and the U.S. District Court for the District of Kansas which specifically discuss the KRTA.

\footnotetext{
109. Id.

110. Id.

111. Id.

112. Id.

113. See, e.g., Seaboard Corp. v. Marsh Inc., 284 P.3d 314 (Kan. 2012); O’Brien v. Leegin Creative Leather Prods., Inc. (O'Brien I), 277 P.3d 1062 (Kan. 2012); Merriman v. Crompton Corp., 146 P.3d 162 (Kan. 2006); Smith v. Philip Morris Cos., 335 P.3d 644 (Kan. Ct. App. 2014); Idstrom v. All. Radiology, P.A., No. 115,099, 2017 WL 129926 (Kan. Ct. App. Jan. 13, 2017); O’Brien v. Leegin Creative Leather Prods., Inc. (O'Brien II), No. 108,988, 2014 WL 1362657 (Kan. Ct. App. Apr. 4, 2014); Hildyard v. Citizens Med. Ctr., No. 105,468, 2012 WL 4794558 (Kan. Ct. App. Oct. 5, 2012); VHC Van Hoecke Contracting, Inc. v. Lennox Indus., Inc., No. 101,024, 2011 WL 2039725 (Kan. Ct. App. May 20, 2011); Suture Express, Inc. v. Owens \& Minor Distribution, Inc., 851 F.3d 1029 (10th Cir. 2017); Reorganized FLI, Inc. v. Williams Cos., 410 F. Supp. 3d 1213 (D. Kan. 2019); In re EpiPen (Epinephrine Injection, USP) Mktg., Sales Practices \& Antitrust Litig., 336 F. Supp. 3d 1256 (D. Kan. 2018); Digital Ally, Inc. v. Taser Int'l, Inc., No. 16-2032, 2017 WL 131595 (D. Kan. Jan. 12, 2017), aff'd, 720 F. App'x 1023 (Fed. Cir. 2018), cert. denied, 139 S. Ct. 231 (2018); Suture Express, Inc. v. Owens \& Minor Distribution, Inc., No. 12-2760, 2016 WL 1377342 (D. Kan. Apr. 7, 2016), aff'd, 851 F.3d 1029 (10th Cir. 2017); Catron v. Colt Energy, Inc., No. 13-4073, 2014 WL 7246804 (D. Kan. Dec. 17, 2014); Layne Christensen Co. v. Bro-Tech Corp., 836 F. Supp. 2d 1203 (D. Kan. 2011); Ablulimir v. U-Haul Co. of Kan., No. 11-4014, 2011 WL 2731774 (D. Kan. July 13, 2011); Associated Wholesale Grocers, Inc. v. United Egg Producers, No. 11-CV-2063, 2011 WL 1113546 (D. Kan. Mar. 24, 2011); Schecher v. Purdue Pharma L.P., 317 F. Supp. 2 d 1253 (D. Kan. 2004); Folkers v. Am. Massage Therapy Ass'n, Inc., No. 03-2399, 2004 WL 306913 (D. Kan. Feb. 10, 2004); Cox v. F. Hoffman-La Roche, Ltd., No. 00 C 1890, 2003 WL 24471996 (Kan. Dist. Ct. Oct. 10, 2003); Four B Corp. v. Daicel Chem. Indus., Ltd., 253 F. Supp. 2d 1147 (D. Kan. 2003); Bellinder v. Microsoft Corp., No. 00-C-00092, 2001 WL 1397995 (Kan. Dist. Ct. Sept. 7, 2001).
} 


\section{Kansas Supreme Court}

Three Kansas Supreme Court cases mentioned the KRTA from 2000 to 2013. The most recent was Seaboard Corp. v. Marsh Inc. ${ }^{114}$ decided on August 31, 2012. The KRTA claim was one of eight brought by an insurance client against an insurance broker and companies related to an alleged "bid-rigging" scheme. ${ }^{115}$ The defendants filed a motion to dismiss alleging the statute of limitations had run. ${ }^{116}$ The defendants filed an interlocutory appeal after the district court denied their motion to dismiss. ${ }^{117}$ Thus, much of the discussion in both the Kansas Supreme Court decision and the underlying decision deals with claim preservation. ${ }^{118}$ The Kansas Supreme Court affirmed the dismissal and noted - similar to the $O^{\prime}$ Brien I decision a few months earlier ${ }^{119}$ - that "statutory analysis must begin with the plain language of the statute." 120 The Kansas Supreme Court does not speculate about legislative intent when statutory language is "plain and unambiguous." 21 The main finding of the Kansas Supreme Court decision did not rest on any tenet of the KRTA. $^{122}$

The district court opinion is much more interesting from an antirust perspective. In discussing the status of claims, the district court noted that private actions brought under the KRTA were subject to a three-year statute of limitations. ${ }^{123}$ In the district court case, the defendants also asked the court to apply the federal Bell Atlantic Corp. v. Twombly ${ }^{124}$ pleading standard to the plaintiff's claims. ${ }^{125}$ The court found that because the Twombly decision clearly related to the Federal Rules of Civil Procedure, it did not apply to a Kansas statutory claim brought under the Kansas Rules of Civil Procedure. ${ }^{126}$ Additionally, "neither the Kansas

\footnotetext{
114. 284 P.3d 314 (Kan. 2012).

115. Id. at 317 .

116. Id. at 316 .

117. Id. at 319 .

118. Id. at 334-36.

119. O’Brien v. Leegin Creative Leather Prods., Inc. (O'Brien I), 277 P.3d 1062, 1073 (Kan. 2012).

120. Seaboard, 284 P.3d at 324, 337.

121. Id. at 324.

122. Id. at 316-17.

123. Seaboard Corp. v. Marsh Inc., No. 09CV9499, 2010 WL 3054216, at*3 (Kan. Dist. Ct. May $3,2010)$.

124. 550 U.S. 544, 570, 555 (2007) (holding that a federal complaint must allege "enough facts to state a claim to relief that is plausible on its face" and the "[f]actual allegations must be enough to raise a right to relief above the speculative level").

125. Seaboard Corp., 2010 WL 3054216 , at *16.

126. Id.
} 
legislature nor the Kansas Supreme Court" had adopted the standard. ${ }^{127}$ Rather, Kansas had a contrary legal standard and until the Kansas Supreme Court repealed it, the district court would continue to abide by the standard. ${ }^{128}$

The second antitrust decision of the Kansas Supreme Court, O'Brien $I,{ }^{129}$ is perhaps the most notable KRTA case of the past two decades. ${ }^{130}$ This Article will discuss this case in conjunction with the legislative changes that resulted in Part III.

The final Kansas Supreme Court antitrust decision of the 2000 through 2013 timeframe-Merriman v. Crompton Corp. - dealt mostly with issues of personal jurisdiction over foreign corporations. ${ }^{131}$ However, the underlying cause of action was a price-fixing conspiracy, and the Kansas Supreme Court found that a price-fixing conspiracy may be a tortious act for purposes of jurisdiction. ${ }^{132}$ The court came to the decision in part "because antitrust violations are generally recognized to be torts," 133 but also because "Kansas has a strong interest in protecting the rights of its citizens and providing a forum convenient for the redress of wrongs done to Kansans."134 Finally, the Kansas Supreme Court felt it best to leave the interpretation of Kansas laws to Kansas courts rather than foreign forums. ${ }^{135}$

\section{Kansas Court of Appeals Decisions}

Kansas Court of Appeals decisions between 2000 and 2013 mostly touch only briefly on the KRTA. The first involved what the court termed a "conclusory" pleading of KRTA damages, and the court found the antitrust claim was barred by immunity provisions under controlling

\footnotetext{
127. $I d$.

128. Id.; see also Rector v. Tatham, 196 P.3d 364, 366 (Kan. 2008) ("When a district court has granted a motion to dismiss for failure to state a claim, an appellate court must accept the facts alleged by the plaintiff as true, along with any inferences that can reasonably be drawn therefrom. The appellate court then decides whether those facts and inferences state a claim based on plaintiff's theory or any other possible theory. If so, the dismissal by the district court must be reversed.") (citation omitted)).

129. O’Brien v. Leegin Creative Leather Prods., Inc. (O'Brien I), 277 P.3d 1062 (Kan. 2012).

130. See Michael L. Fessinger, Comment, A Century Behind? The Kansas Supreme Court Opts Out of the Rule of Reason in O'Brien v. Leegin Creative Leather Prods., Inc., 52 WASHBURN L.J. 323, 324 (2013) ("Following the O'Brien decision, Kansas became the first state whose highest court came down against the rule of reason framework since the U.S. Supreme Court applied it to questions of vertical price fixing in 2007.").

131. 146 P.3d 162, 166-67 (Kan. 2006).

132. Id. at 181 .

133. Id. at 180 .

134. Id. at 187 .

135. Id.
} 
federal law. ${ }^{136}$ In a second case, the KRTA claims were dismissed on summary judgment, and the case continued regarding tortious interference with a business relationship; the KRTA dismissal was not appealed. ${ }^{137}$ General antitrust principles, including boycott, are discussed in the decision, but not the KRTA itself. ${ }^{138}$ Finally, a KRTA claim was brought by a civilly committed sex offender as part of a habeas petition. ${ }^{139} \mathrm{He}$ alleged the defendant hospital violated the KRTA because it would only allow him to buy materials from the hospital's own canteen. ${ }^{140}$ The court found the matter did not rise to the level of a constitutional violation to be appropriately considered on a habeas petition. ${ }^{141}$

\section{U.S. District Court of Kansas Decisions}

Between 2000 and 2013, no United States Supreme Court or Tenth U.S. Circuit Court of Appeals decisions were issued that discussed the KRTA. Five cases discussing the KRTA were decided by the U.S. District Court of Kansas during that timeframe.

Ablulimir v. U-Haul Co. of Kansas began in state court but was removed to federal court. ${ }^{142}$ The plaintiff, who ran a rental business, sued U-Haul for failing to renew a contract with her dealership, allegedly attempting to run her out of business, and conspiring to open a new dealership before terminating her contract. ${ }^{143}$ The plaintiff generally alleged antitrust violations amid her other allegations. The court found that the Kansas Supreme Court had indicated that the question at issue was "whether the restraint is reasonable and whether or not the restraint contravenes the public welfare." 144 The court noted that the KRTA protects competition, not competitors, and dismissed the plaintiff's claim. ${ }^{145}$

In Layne Christensen Co. v. Bro-Tech Corp.-a 2011 noncompete lawsuit involving a license for a patent to remove arsenic and other

136. Hildyard v. Citizens Med. Ctr., No. 105,468, 2012 WL 4794558, at*16 (Kan. Ct. App. Oct. 5,2012 ) ("[Defendant] is immune under the [Health Care Quality Improvement Act], even from damages for antitrust violations.").

137. VHC Van Hoecke Contracting, Inc. v. Lennox Indus., Inc., No. 101,024, 2011 WL 2039725, at $* 7$ (Kan. Ct. App. May 20, 2011).

138. Id. at *12-13.

139. Merryfield v. Kan. Soc. \& Rehab. Servs. (SRS), No. 102,384, 2009 WL 5206252, at*1 (Kan. Ct. App. Dec. 31, 2009).

140. Id.

141. Id. at $* 4$.

142. No. 11-4014, 2011 WL 2731774 , at*1 (D. Kan. July 13, 2011).

143. $I d$.

144. Id. at*6 (citing Heckard v. Park, 188 P.2d 926, 931 (Kan. 1948)).

145. Id. 
contaminants from fluids - the owners and licensor sued the licensee alleging patent infringement and breach of contract. ${ }^{146}$ The licensee brought a counterclaim asserting, inter alia, a restraint of trade claim based on the noncompete provision of the agreement. ${ }^{147}$ The plaintiffs sought summary judgment on the claim, arguing that the contractual provision was not an unreasonable restraint of trade. ${ }^{148}$ The court noted the lack of meaningful interpretation of the statute at the time, reviewed a string of reasonableness standard cases from the 1940s and 50s, and noted a Kansas Supreme Court case from 1949 in which a contract with a noncompete clause was deemed reasonable. ${ }^{149}$ Based on its review of Kansas Supreme Court rulings, the court was convinced that the Kansas Supreme Court would reject the antitrust challenge and awarded summary judgment. ${ }^{150}$

In Schecher v. Purdue Pharma L.P., the court found that issues of Kansas law can be removed from state court and joined in multidistrict litigation when allegations are closely related to those in the other litigation and substantial questions of federal law are raised by the pleadings. ${ }^{151}$ This facilitates the interest of justice and avoids inconsistent results. ${ }^{152}$ In another case, the court found that a plaintiff's failure to cite a specific provision of the KRTA failed to put the defendant on notice of the claim against them, and made an inquiry to determine analogous federal statutes impossible, which warranted dismissal of the claim. ${ }^{153}$

In 2003, the federal district court held that indirect purchasers have "antitrust standing" under the KRTA to sue for full consideration damages. ${ }^{154}$ The court also found indirect purchasers had standing to pursue treble damages under another KRTA provision. ${ }^{155}$ The Kansas Supreme Court had not ruled on the matter, so the district court used Smith v. Phillip Morris Cos. (an unpublished opinion from the District Court of Seward County), the plain language of the KRTA, and the "sparse record at this stage of the proceedings" to make its ruling on indirect purchaser standing. ${ }^{156}$ The federal district court adopted the reasoning of the Smith decision and found that the Kansas legislature amended state antitrust law

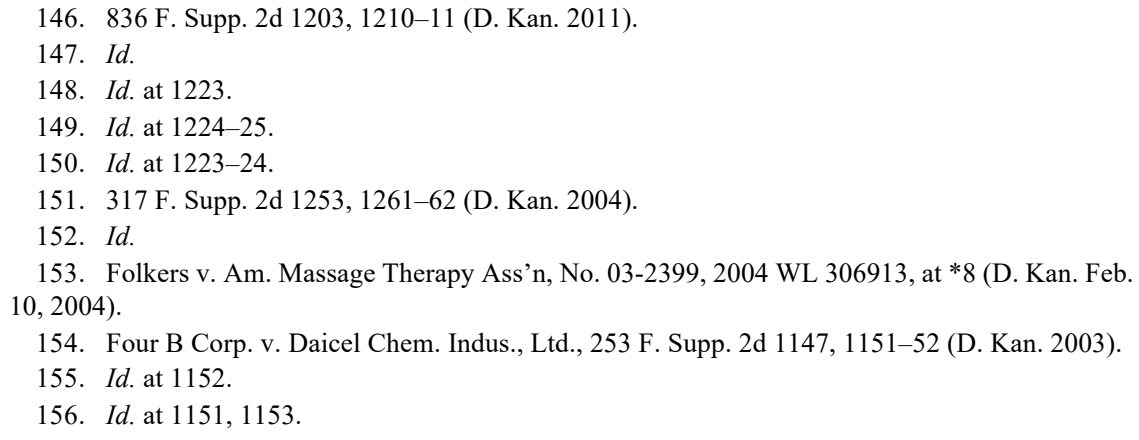


in 1985 by placing specific language in the treble damages provision of the statute to indicate the State's intent to allow indirect purchaser actions despite the Supreme Court's 1977 ruling that such actions were disallowed under federal antitrust statutes. ${ }^{157}$ The specific placement of the language did not reflect a legislative intent to preclude an indirect purchaser's recovery of full consideration damages; rather the legislature found the full consideration provision to be sufficient to allow for indirect purchaser recovery. ${ }^{158}$

\section{THE O'BRIEN V. LEEGIN DECISION AND SUBSEQUENT LEGISLATIVE CHANGE}

O'Brien v. Leegin is of particular note for Kansas because there were actually two Leegin cases — one decided by the U.S. Supreme Court, ${ }^{159}$ which did not originate in Kansas, and one decided by the Kansas Supreme Court. ${ }^{160}$ The cases were pursued concurrently-one in federal court on issues of federal law and one in state court on issues of state law. The federal case involved a dispute between retailers, while the Kansas case was a class action suit. ${ }^{161}$ Both cases involved the same defendant and similar allegations that the defendant's retail price maintenance program was anticompetitive and violative of antitrust laws. ${ }^{162}$ The U.S. Supreme Court decision came down on June 28, 2007, ${ }^{163}$ and the Sedgwick County District Court entered judgment in the state case on July 17, 2008. ${ }^{164}$ The Kansas decision was appealed. ${ }^{165}$ In the state-law case, the Kansas courts were not bound by the U.S. Supreme Court decision because the Kansas Supreme Court had long espoused the view that "[w]hile... cases [interpreting federal antitrust statutes] may be persuasive authority for any state court interpreting its antitrust laws, such authority is not binding upon any court in Kansas interpreting Kansas antitrust laws."166

The U.S. Supreme Court's Leegin decision found that application of the per se rule to vertical minimum resale pricing agreements was

\footnotetext{
157. Id. at $1151-52$.

158. Id. at $1152-53$.

159. Leegin Creative Leather Prods., Inc. v. PSKS, Inc., 551 U.S. 877 (2007).

160. O’Brien v. Leegin Creative Leather Prods., Inc. (O'Brien I), 277 P.3d 1062 (Kan. 2012).

161. Leegin, 551 U.S. 877; O'Brien I, 277 P.3d 1062.

162. Leegin, 551 U.S. at 881-84; O'Brien I, 277 P.3d at 1068-69.

163. Leegin, 551 U.S. 877.

164. O’Brien v. Leegin Creative Leather Prods., Inc., No. 04CV1668, 2008 WL 10635349 (Kan. Dist. Ct. July 17, 2008), rev'd and remanded, 277 P.3d 1062 (Kan. 2012).

165. See O'Brien I, 277 P.3d at 1067 ("We transferred this matter from our Court of Appeals on O'Brien's unopposed motion.").

166. Id. at 1068 (citing Bergstrom v. Noah, 974 P.2d 520, 531 (Kan. 1999)).
} 
unwarranted. ${ }^{167}$ In doing so, the Court overruled Dr. Miles Medical Co. v. John D. Park \& Sons Co., ${ }^{168}$ which had been accepted precedent for almost a century. The Kansas Supreme Court, ruling five years later, found to the contrary. The Kansas Supreme Court rejected the defendant's argument that the court should apply the same "rule of reason" analysis the U.S. Supreme Court applied in Leegin - a case involving "at least some of the same pricing practices at issue here."169 Instead, the Kansas Supreme Court found that "[n]either K.S.A. § 50-101 nor K.S.A. § 50-112 mentions reasonableness or a rule of reason." $" 170$

The Attorney General submitted an amicus brief in the matter arguing that the legislature had declared retail price maintenance against public policy, federal precedents applying the rule of reason were inapplicable and unpersuasive given the differences between federal and state law, and the bright line rule laid out by the legislature was more practically beneficial than a rule of reason, giving clarity to market participants. ${ }^{171}$ The Kansas Supreme Court found the statutory language of the KRTA drew a bright line rule, and federal antitrust rulings compelled nothing of them. ${ }^{172}$ The court instead considered the legislative and case law history of antitrust in Kansas, ${ }^{173}$ finding that neither prior cases nor the clear language of the statute justified reading a "reasonableness rubric" into a price-fixing arrangement or the KRTA. ${ }^{174}$ The Kansas Supreme Court's decision reaffirmed that despite the existence of federal antitrust statutes, such as the Sherman Act, and much case law interpreting such federal law, "antitrust law has traditionally been the province of the states." 175 The court ultimately found that " $[\mathrm{b}]$ ecause this state court case arises under the KRTA rather than federal law, the rule of reason does not apply." "176 Rather, the plain language of Kansas statutes governed. The case had been

\footnotetext{
167. Leegin, 551 U.S. at 882.

168. 220 U.S. 373 (1911).

169. O'Brien I, 277 P.3d at $1078-79$.

170. Id.

171. See Brief for the States of New York et al. as Amici Curiae Supporting Respondent, Leegin Creative Leather Prods. v. PSKS, Inc., 551 U.S. 877 (Feb. 26, 2007) (No. 06-480).

172. O'Brien I, 277 P.3d at 1079 ("[F]ederal precedents interpreting, construing, and applying federal statutes have little or no precedential weight when the task is interpretation and application of a clear and dissimilar Kansas statute.").

173. Id. at $1079-82$.

174. Id. at 1082 ("Careful examination of Heckard and Okerberg demonstrates that the 'reasonableness' rubric they instituted had and has nothing to do with evaluation of an alleged pricefixing arrangement .... [A] more basic reason not to apply the reasonableness rubric ... [is that] we are loathe to read unwritten elements into otherwise clear legislative language.").

175. Id. at 1067-68; see also McShares, Inc. v. Barry, 970 P.2d 1005, 1012 (Kan. 1998) ("Congress intended the federal antitrust laws to supplement, not displace, state antitrust remedies." (citation omitted)).
}

176. O'Brien I, 277 P.3d at 1084 . 
decided on summary judgment at the lower court and other issues - such as class certification - remained, so the case was reversed and remanded to the lower court for further proceedings. ${ }^{177}$

Immediately following the Kansas Supreme Court decision in O'Brien $I$, opponents of the decision sought a statutory change to the KRTA. The first bill proposing to amend the KRTA was introduced May 10, 2012six days after the court's decision. ${ }^{178}$ House Bill 2797 was introduced to "correct the interpretation of the Kansas restraint of trade act, K.S.A. § 50101 through 50-162, and amendments thereto, made in O'Brien v. Leegin Creative Leather Products, Inc." ${ }^{179}$ The proposed bill contained a provision which stated an "arrangement, contract, agreement, trust, understanding or combination" was not a trust (and therefore unlawful) if it "would be deemed a reasonable restraint of trade or commerce under Section 1 of the Sherman Act, 15 U.S.C. $§ 1$, as construed and interpreted by the federal courts." 180 The proposed bill also prohibited antitrust class actions and applied retroactively to all pending and future litigation. ${ }^{181}$

Numerous individuals, businesses, and interest groups submitted written testimony to the House Judiciary Committee which held a hearing on the bill on May 11, 2012. ${ }^{182}$ Opinions were mixed and even parties

177. Id. at 1067,1072 . The matter was appealed again post-remand to the Kansas Court of Appeals, which noted in its opinion:

In direct response to the Kansas Supreme Court's earlier decision in this case, the Kansas Legislature made significant amendments to the Kansas Restraint of Trade Act, effective April 18, 2013. That statute now allows for "reasonable restraint of trade" and has declared that its provisions will be "construed in harmony" with the United States Supreme Court's antitrust decisions. In addition, the legislature repealed K.S.A. 50-108 and K.S.A. 50-115, the statutes that provided for actual damages and what are called full-consideration damages.... And the legislature declared that its new provision allowing reasonable restraint of trade should apply retroactively except for cases, like this one . . . .

The end result is that most of O'Brien's precedential value is limited to this case and any other case that was already pending before April 18, 2013. Accordingly, our opinion in this case will have very limited precedential value going forward regarding issues arising under the Kansas Restraint of Trade Act.

O’Brien v. Leegin Creative Leather Prods., Inc. (O'Brien II), No. 108,988, 2014 WL 1362657, at *5 (Kan. Ct. App. Apr. 4, 2014) (internal citations omitted).

178. H.B. 2797, 84th Leg., 2012 Reg. Sess. (Kan. 2012).

179. Id.

180. Id. $\S 1(\mathrm{a})$.

181. Id. § 1 (b)-(c).

182. Kansas Restraint of Trade Act: Hearing on H.B. 2797 Before the H. Judiciary Comm., 84th Leg., 2012 Reg. Sess. (Kan. 2012) (statements of Dale Rodman, Secretary of Agriculture, Kansas Department of Agriculture; Professor Michael Hoeflich, University of Kansas School of Law; the National Cattleman's Beef Association; Jeffrey Jordon, the Association of Ethanol Processors; the Kansas Grain \& Feed Association; the Kansas Agribusiness Retailers Association; the Kansas Cooperative Council; the Kansas Chamber; Patrick Stueve of Stueve, Siegel, \& Hanson, LLP; Rex Sharp of Gunderson, Sharp \& Walke, LLP; the Kansas Association for Justice; former Attorney General Steve Six; and Deborah B. McIlhenny of Hutton \& Hutton, LLC). 
who felt the law should be amended did not necessarily feel Kansas House Bill 2797 was the proper solution. ${ }^{183}$ The bill ultimately died in committee. ${ }^{184}$

In the following legislative session in 2013, six bills were proposed to change the KRTA. ${ }^{185}$ Two of the bills proposed to repeal the KRTA completely. Those two bills, introduced by different House Committees, were identical; both died in committee. ${ }^{186}$ Five of the six bills were introduced in the House or Senate Judiciary Committees.

Four bills proposing amendment to KRTA were introduced: Kansas Senate Bill 123, Kansas Senate Bill 124, Kansas House Bill 2224, and Kansas House Bill 2275. Kansas Senate Bill 123 and Kansas House Bill 2275 were identical. Kansas Senate Bill 123, Kansas House Bill 2275 and Kansas House Bill 2224 proposed to amend existing statutes K.S.A. § 50101 and $\S 50-112$. Kansas Senate Bill 124 proposed amending K.S.A. $\S$ $50-101, \S 50-112$, and $\S 50-161$. The goal of all four amendment proposals was to replace the "per se" standard with a "reasonableness" standard. ${ }^{187}$ Despite this commonality, the four bills differed in both language and substance.

Kansas Senate Bill 123, Kansas House Bill 2275, and Kansas Senate Bill 124 added a four-factor test to determine whether a trust is a "reasonable restraint of trade." The test was identical in each bill. ${ }^{188}$ The test was similar, but not identical, to the federal test set out by the U.S. Supreme Court. ${ }^{189}$ Kansas House Bill 2224 did not include the new fourfactor test for reasonableness, and the test was struck from Kansas Senate Bill 124 in the legislative process. ${ }^{190}$ Each bill exempted certain entities

183. For instance, Eric Stafford, Senior Director of Governmental Affairs for the Kansas Chamber, stated that "we simply need more time before we can support HB 2797 to make sure there are no unintended consequences." Id.

184. See HB 2797, KAN. LEG., http://www.kslegislature.org/li_2012/b2011_12/measures/hb2797/ [https://perma.cc/3PZV-XZPL] (last visited Apr. 12, 2020).

185. S.B. 123, 85th Leg., 2013 Reg. Sess. (Kan. 2013); S.B. 124, 85th Leg., 2013 Reg. Sess. (Kan. 2013); H.B. 2224, 85th Leg., 2013 Reg. Sess. (Kan. 2013); H.B. 2275, 85th Leg., 2013 Reg. Sess. (Kan. 2013); H.B. 2258, 85th Leg., 2013 Reg. Sess. (Kan. 2013); S.B. 2225, 85th Leg., 2013 Reg. Sess. (Kan. 2013).

186. Kan. S.B. $2225 \S 3$; Kan. H.B. $2258 \S 3$.

187. Kan. S.B. $123 \S 1$ (b)(1); Kan. S.B. $124 \S 1$ (b)(1); Kan. H.B. $2224 \S 1$ (b)(1); Kan. H.B. 2275 $\S 1(b)(1)$.

188. Kan. S.B. $124 \S 1(b)(2) ;$ Kan. H.B. $2275 \S 1(b)(2) ;$ Kan. S.B. $123 \S 1(b)(2)$.

189. Leegin Creative Leather Prods., Inc. v. PSKS, Inc., 551 U.S. 877, 885-86 (2007) ("Appropriate factors to take into account include 'specific information about the relevant business' and 'the restraint's history, nature, and effect.' Whether the businesses involved have market power is a further, significant consideration." (citations omitted)).

190. Kan. S.B. 124 (as amended by the Senate Judiciary Committee). Prior versions of S.B. 124 included a list of factors that Kansas courts would need to consider when making the reasonableness 
from the prohibitions of the KRTA. A select few entities were exempted in all proposed bills, but others were only proposed in one or two of the bills. ${ }^{191}$ Kansas Senate Bill 124 added a section amending existing statute K.S.A. § 50-161. ${ }^{192}$ The new section limited the allowable damages to be sought under the KRTA to either actual damages or those damages allowed by existing statute K.S.A. $\S 50-115 .{ }^{193}$ This addition was not present in Kansas Senate Bill 123 or Kansas House Bill 2224. Ultimately, Kansas Senate Bill 124 took the day; it was passed by both chambers and was signed by the Governor on April 16, 2013. ${ }^{194}$

We won't take a deep dive into the 2013 statutory change. Several previous articles have explored the legislative and policy changes of Kansas Senate Bill 124. ${ }^{195}$ But several key changes are worth noting. The 2013 amendment added a federal harmonization provision with exemptions for attorney general enforcement, indirect purchaser suits, and intrastate commerce. ${ }^{196}$ The retroactive application of the statute is discussed further in Part V. ${ }^{197}$ Several areas were explicitly excluded from the jurisdiction of the KRTA. ${ }^{198}$ Ironically, one exclusion was any agreement governed by the provisions of the Packers and Stockyards Act. ${ }^{199}$

Finally, the amendment changed the standard of review under Kansas antitrust law to a reasonableness standard. ${ }^{200}$ It is important to note that despite including a federal harmonization provision in the KRTA, the amendment did not adopt the federal rule of reason standard. The Kansas

determination. The final version eliminated these factors and instead directed courts to consider "all of the facts and circumstances of the particular case.” Kan. S.B. $124 \S 1$ (c).

191. For example, Kansas Senate Bill 123 and Kansas House Bill 2275 exempted group purchasing organizations or cooperatives "engaged in coordinated purchasing activities designed to obtain lower prices or increase efficiencies for its members so long as it does not possess monopoly power." Kansas House Bill2224 and Kansas Senate Bill 124 did not contain this exemption.

192. Kan. S.B. $124 \S 4(a)-(c)$.

193. Id. $\S 4(\mathrm{~b})$.

194. See Bills \& Laws, KAN. LEG., http://www.kslegislature.org/li_2014/b2013_14/measures /sb124/ [https://perma.cc/US38-DDHV] (last visited Apr. 12, 2020).

195. See, e.g., Joshua A. Ney, The Revised KRTA: O'Brien and the Legislative Response, 53 WASHBURN L.J. 265, 286-93 (2014); Fessinger, supra note 130, at 353 (discussing the Kansas Legislature's response to O'Brien I).

196. KAN. StaT. ANN. § 50-163(b), (d) (2013).

197. See infra Part V.

198. Id. §50-163(e).

199. See id. $\S 50-163(\mathrm{e})(5)$.

200. Id. § 50-163(c); see also Melissa Lipman, New Kansas Law Undoes Antitrust Ruling on Resale Pricing, LAw360 (Apr. 18, 2013, 10:17 PM), http://www.law360.com/articles/433994/print ?section=competition [https://perma.cc/YTA2-576X] ("Now Kansas courts will have to consider whether arrangements that 'are not intended to unreasonably restrain trade or commerce and do not contravene public [welfare]' are illegal 'in view of all of the facts and circumstances of the particular case."'). 
Legislature chose not to establish a test similar to that established by the U.S. Supreme Court, instead leaving the standard vaguely defined as "reasonableness" based on a review of the facts and circumstances. ${ }^{201}$ Additionally, to the extent U.S. Supreme Court judicial interpretations are in conflict with or inconsistent with the reasonableness provision of the Kansas law, the Kansas reasonableness provision would control. ${ }^{202}$ The provision returned Kansas law to the reasonableness standard found in earlier Kansas case law. All Kansas Supreme Court and Court of Appeals decisions since the amendment of the statute have applied pre-amendment statutory interpretation to the matter, as they were instituted prior to the statutory change. The Kansas Court of Appeals noted that the changes included:

(1) The repeal of the full-consideration damages provision in K.S.A. 50115 , which allowed a successful plaintiff to recover the full consideration paid for goods "controlled in price by such combination" ...; (2) a declaration that provisions of the KRTA shall be "construed in harmony" with the United States Supreme Court's interpretations of federal antitrust law; and (3) permitting a rule-of-reason analysis by an explicit allowance for "reasonable restraint[s] of trade or commerce.",

\section{KANSAS ANTITRUST ENFORCEMENT SinCE THE 2013 AMENDMENT OF THE KRTA}

\section{A. Attorney General Antitrust Enforcement Since 2013}

Antitrust cases in recent years have been increasingly complex. One aspect of this involves the introduction of eDiscovery and the need to cull millions of electronic documents, which has affected the size and timing of litigation. ${ }^{204}$ Additionally, in recent years, more Defendants have fought Attorney General claims and refused, at least initially, to settle than in the past. The Attorney General has pursued matters in the same categories as before the 2013 amendments to the KRTA: pharmaceutical drugs, consumer goods, government and nonprofit investments, and mergers, with the addition of technological services.

201. KAN. STAT. ANN. §50-163(c).

202. Id. §50-163(b) ("If such judicial interpretations [by the United States Supreme Court] are in conflict with or inconsistent with the express [reasonableness] provisions of subsection (c), the provisions of subsection (c) shall control.").

203. Smith v. Philip Morris Cos., 335 P.3d 644, 652 (Kan. Ct. App. 2014).

204. Steven Bennett, E-Discovery: Reasonable Search, Proportionality, Cooperation, and Advancing Technology, 30 J. MARShALl J. INFO. TECH. \& PRIVACY L. 433, 445-48 (2014) (highlighting new challenges that come with advancing technology with respect to eDiscovery). 


\section{Pharmaceutical Drugs}

The Attorney General brought four pharmaceutical drug lawsuits between 2013 and 2019. Three of them are still in litigation at the time of this writing. The first matter, New York v. Cephalon, Inc., involved a company that engaged in anticompetitive conduct to keep a generic competitor off the market. ${ }^{205}$ The Attorney General, with forty-eight other states and the District of Columbia, negotiated a settlement with Cephalon and its co-conspirators prior to filing suit. ${ }^{206}$ The FTC had settled with the company prior to the States' suit and set up an escrow fund, from which the States were able to recover. ${ }^{207}$ Cephalon, the brand drug company, had filed for a fraudulent patent to preserve its patented drug monopoly that was reaching expiration ${ }^{208}$ - a patent that a court later deemed to be invalid and unenforceable. ${ }^{209}$ Prior to the court finding, Cephalon filed patent infringement cases to keep generic competitors from introducing a generic alternative. ${ }^{210}$ When Cephalon brought suit against potential competitors, it would settle those suits by paying its potential competitors to delay their sale of the generic drug. ${ }^{21}$ That conduct delayed generic versions of the drug from entering the market for several years, causing consumers and governmental health providers to pay higher prices for the branded version of the drug. ${ }^{212}$

The second pharmaceutical matter the Attorney General is pursuing is still in litigation at the time of this writing. In 2016, the Attorney General and thirty-four other States and the District of Columbia filed suit alleging the makers of Suboxone, an opioid addiction treatment drug, had conspired to block generic competition by switching the drug from a tablet

205. Complaint at 1-2, New York v. Cephalon, Inc., No. 16-cv-4234 (E.D. Pa. Aug. 4, 2016).

206. Order Granting Final Approval for Settlement at 1, New York v. Cephalon, Inc., No. 16-cv4234 (E.D. Pa. July 25, 2017) ("Plaintiff States and Cephalon, Inc. ... entered into a Settlement Agreement dated July 28, 2016.").

207. See Stipulated Order for Permanent Injunction and Equitable Monetary Relief at 1, FTC v. Cephalon, 2:08-cv-2141 (E.D. Pa. June 17, 2015), https://www.ftc.gov/system/files/documents/cases /150617cephalonstip.pdf; Press Release, Fed. Trade Comm'n, FTC Settlement of Cephalon Pay for Delay Case Ensures \$1.2 Billion in Ill-Gotten Gains Relinquished; Refunds Will Go To Purchasers Affected By Anticompetitive Tactics (May 28, 2015, 11:00 AM), https://www.ftc.gov/news-events /press-releases/2015/05/ftc-settlement-cephalon-pay-delay-case-ensures-12-billion-ill [https://perma .cc/74XR-EEW4].

208. Complaint, New York v. Cephalon, Inc., supra note 205, at 13-16.

209. Apotex Inc. v. Cephalon, Inc., No. 06-cv-2768, 2011 WL 6090696, at*1, (E.D. Pa. Oct. 31, 2011) (finding Cephalon's Formulation Patent invalid).

210. Complaint, New York v. Cephalon, Inc., supra note 205, at 16-18.

211. Id. at $19-24$.

212. See id. 
to a dissolving film in a scheme called "product hopping." 213 This is accomplished by making small formulation changes to the product so that pharmacies cannot automatically substitute a generic drug for the new version of the brand. ${ }^{214}$ The suit also alleges that the Defendant fabricated false safety concerns and manipulated the Food and Drug Administration approval process. ${ }^{215}$ Since the complaint was filed, additional states have joined the litigation. ${ }^{216}$ The original complaint was filed against four Defendants, but the court dismissed claims against Reckitt Benckiser Healthcare (UK) Ltd. on October 17, 2017, and dismissed claims against Indivior PLC on October 25, 2017. ${ }^{217}$ Litigation continues against Indivior, Inc., and MonoSol Rx, LLC.

The DOJ has taken criminal action against two related companies, indicting Indivior, Inc., a defendant in the case, and Indivior PLC for "engaging in an illicit nationwide scheme to increase prescriptions of Suboxone Film." "218 The DOJ also settled a case against Indivior's former parent company, Reckitt Benckiser Group plc, which the States did not sue, to resolve potential criminal and civil liability related to a federal investigation of the marketing of Suboxone. ${ }^{219}$ There is also an ongoing concurrent private class action filed in the same court as the States' case. ${ }^{20}$ Because the matter is still pending, nothing further can be said about the case at this time.

The final two pharmaceutical cases being pursued by the Attorney

213. Wisconsin v. Indivior, Inc. (In re Suboxone Antitrust Litig.), No. 16-cv-5703, 2017 WL 4810801, at*1 (E.D. Pa. Oct. 25, 2017).

214. Id.; Complaint at 11-18, Wisconsin v. Indivior, Inc. (In re Suboxone Antitrust Litig.), No. 16-cv-5703 (E.D. Pa. Aug. 15, 2013), 2017 WL 4810801.

215. Indivior, $2017 \mathrm{WL} 481080$, at *1 (alleging that Indivior "refus[ed] to participate in a joint REMS safety program and fil[ed] a baseless citizen petition").

216. DereK SCHMidt, KAN. ATt'y Gen., 2016 CONSUMER ProteCtion \& ANTITRUST Division ANNUAL REPORT 17 (2017), https://ag.ks.gov/docs/default-source/documents/2016-consumer -protection-annual-report.pdf?sfvrsn=dfc0d51a_4 [https://perma.cc/Y8BG-QEEU] (“An amended complaint was filed on November 16, 2016, which added additional state plaintiffs, bringing the total number of states to 42."); see also Dan Packel, 6 More States Join Suboxone Product-Hopping Lawsuit, LAw360 (Nov. 18, 2016, 1:52 PM), https://www.law360.com/articles/864208/6-more -states-join-suboxone-product-hopping-lawsuit.

217. See Order at 1, Wisconsin v. Indivior, Inc. (In re Suboxone Antitrust Litig.), No. 16-5703, 2017 WL 4810801 (E.D. Pa. Oct. 16, 2017); Memorandum Opinion at 1, Wisconsin v. Indivior, Inc. (In re Suboxone Antitrust Litig.), No. 16-5703, 2017 WL 4810801 (E.D. Pa. Oct. 25, 2017).

218. Press Release, U.S. Dep't of Justice, Indivior Inc. Indicted for Fraudulently Marketing Prescription Opioid (Apr. 9, 2019), https://www.justice.gov/opa/pr/indivior-inc-indicted-fraudulently -marketing-prescription-opioid [https://perma.cc/U4PJ-VPSG].

219. Press Release, U.S. Dep't of Justice, Justice Department Obtains \$1.4 Billion from Reckitt Benckiser Group in Largest Recovery in a Case Concerning an Opioid Drug in United States History (July 11, 2019), https://www.justice.gov/opa/pr/justice-department-obtains-14-billion-reckitt -benckiser-group-largest-recovery-case [https://perma.cc/J6NH-BQ2C].

220. See In re Suboxone Antitrust Litig., No. 2:13-md-02445, 2019 WL 4735520, at *1 (E.D. Pa. Sept. 27, 2019). 
General are lawsuits against generic drug manufacturers. The first was filed in 2016 against six generic drug companies alleging they had entered into a longstanding illegal conspiracy to unreasonably restrain trade, artificially inflate and manipulate prices and reduce competition in the United States for two drugs: Doxycycline Hyclate Delayed Release, an antibiotic, and Glyburide, an oral diabetes medication. ${ }^{221}$ The price of the drugs was allegedly manipulated through price-fixing and price maintenance, market allocation, and similar anticompetitive acts. ${ }^{222}$ The complaint alleges that the conspiracy was conceived and carried out by senior drug company executives and their marketing and sales executives, who coordinated through meetings with their competitors at industry trade shows and other events, as well as through email, phone and messaging. ${ }^{223}$

Since that initial filing, the complaint has been amended to include forty-seven states, the District of Columbia and Puerto Rico, and the litigation was transferred through the multidistrict litigation process to the Eastern District of Pennsylvania. ${ }^{224}$ The complaint has been expanded to include fourteen additional defendants and thirteen additional drugs about which the companies are alleged to have entered into conspiracies. ${ }^{225}$ Litigation is still pending.

In March 2017, cooperation and settlement agreements were reached with two former executives of Heritage Pharmaceuticals, Inc.: Jeffrey Glazer, ${ }^{226}$ the company's former chairman and chief executive officer, and Jason Malek, ${ }^{227}$ the former president of Heritage. Kansas has since entered into similar agreements with several more executives of other companies.

In May of 2019, the Attorney General and forty-six other state attorneys general filed a second complaint against eighteen generic pharmaceutical companies and certain company executives, alleging an overarching conspiracy to artificially inflate and manipulate prices and

221. Complaint at 2, Connecticut v. Aurobindo Pharma USA, Inc., No. 3:16 cv-02056 (D. Conn. Dec. 15, 2016), 2016 WL 7242624.

222. Id. at 4-5.

223. Id.

224. See generally Plaintiff States' Consolidated Amended Complaint, Connecticut v. Aurobindo Pharma USA, Inc., No. 2:17-cv-03768 (E.D. Pa. filed Dec. 14, 2016); In re Generic Pharm. Pricing Antitrust Litig., 315 F. Supp. 3d 848 (E.D. Pa. 2018).

225. See Plaintiff States' Consolidated Amended Complaint, Connecticut v. Aurobindo Pharma USA, Inc., supra note 224, at 1-2.

226. State Attorneys General Settlement Agreement with Jeffery Glazer (Mar. 17, 2017), https:// portal.ct.gov/-/media/AG/Press_Releases/2017/20170512GenericDrugsGlazerSettlementAgreement PDF.PDF?la=en [https://perma.cc/4PHW-P6TZ].

227. State Attorneys General Settlement Agreement with Jason Malek (Mar. 21, 2017), https:// portal.ct.gov/-/media/AG/Press_Releases/2017/20170512GenericDrugsMalekSettlementAgreement PDF.PDF?la=en [https://perma.cc/SS2J-HATZ]. 
reduce competition for more than 100 additional generic drugs. ${ }^{228}$ These drugs treat various conditions including basic infections, diabetes, cancer, epilepsy, multiple sclerosis, HIV, and ADHD, as well as including antidepressants, contraceptives, and anti-inflammatory drugs. ${ }^{229}$ An amended complaint was filed in November 2019, adding additional plaintiff states. ${ }^{230}$ This case is also still pending at the time of this writing.

\section{Consumer Goods}

In 2012, Kansas joined a second amended complaint against Apple and five major publishers. ${ }^{231}$ The lawsuit alleged a hub and spoke conspiracy against Apple and five major publishers - that the publishers had conspired with other book publishers and Apple to artificially raise prices by imposing a new distribution model under which the publishers set the prices for bestsellers at $\$ 12.99$ and $\$ 14.99 .^{232}$ When Apple entered the eBook market, the publishers and Apple agreed to adopt an agency distribution model which relied on contract terms which forced eBook sellers to sell the products at the same price. ${ }^{233}$ Because the publishers agreed to use the same prices, retail price competition was eliminated. The States alleged that Apple orchestrated the conspiracy with the publishers. ${ }^{234}$ The States sued only three of the conspirators in the

228. Complaint at 1-3, Connecticut v. Teva Pharm. USA, Inc., No. 3:19-cv-00710 (D. Conn. May 10, 2019).

229. Id. at 25 .

230. See generally Amended Complaint, Connecticut v. Teva Pharm. USA, Inc., No. 2:19-cv02407 (D. Conn. Nov. 1, 2019).

231. See Second Amended Complaint for Injunctive Relief, Civil Penalties \& As Parens Patriae on Behalf of Consumers at 2, Texas v. Penguin Grp. (USA) Inc., No. 1:12-cv-03394 (S.D.N.Y. May 17, 2012). Kansas and seventeen other states joined the litigation a few months after the original suit was filed. In the original suit, there were sixteen plaintiffs - fifteen states and Puerto Rico. See Complaint for Injunctive Relief, Civil Penalties \& As Parens Patriae on Behalf of Consumers at 2-3, Texas v. Penguin Grp. (USA) Inc., No. 1:12-cv-03394 (W.D. Tex. Apr. 11, 2012) [hereinafter Initial Complaint, Texas v. Penguin Grp.]. The Attorney General joined the Ebook litigation in 2012, prior to the 2013 amendments to the KRTA, but the litigation continued until 2016, so we have included the discussion in this Part.

232. Initial Complaint, Texas v. Penguin Grp., supra note 231, at 16. A hub and spoke conspiracy is one in which:

[T]he "hub," coordinates an agreement among competitors at a different level, the "spokes." These arrangements consist of both vertical agreements between the hub and each spoke and a horizontal agreement among the spokes "to adhere to the [hub's] terms," often because the spokes "would not have gone along with [the vertical agreements] except on the understanding that the other [spokes] were agreeing to the same thing."

United States v. Apple, Inc., 791 F.3d 290, 314 (2d Cir. 2015) (alterations in original) (internal citations omitted) (quoting 6 PHILLIP E. AREEDA \& HERBERT HOVENKAMP, ANTITRUST LAW 1402c (3d ed. 2010)).

233. Initial Complaint, Texas v. Penguin Grp., supra note 231, at 16-17.

234. See id. 
litigation because the other three had agreed to settle with the DOJ prior to the filing, and all three agreed to settle with the States prior to the May 2012 filing. ${ }^{235}$

As the case progressed, the divergences between federal and state law were discussed and briefed. The court ordered the States to file supplemental briefing regarding their state law claims, providing copies of the relevant state laws, case law enumerating the elements of state law claims, and "authority describing the extent to which any finding under Section 1 of the Sherman Act might affect those state law claims."236 The court then suggested at the Final Pretrial Conference that the States voluntarily dismiss any state law claims that were not congruent with Section I of the Sherman Act.

The 2013 amendments to the KRTA had added provisions which harmonized federal and state law: "the Kansas restraint of trade act shall be construed in harmony with ruling judicial interpretations of federal antitrust law by the United States Supreme Court."237 However, the lawsuit was filed prior to the amendment of the Act. The amendments to the Act applied retroactively except "causes of action that were pending in any court before the effective date of this act, shall not be abated."238 Thus, there was no statutory provision or case law which indicated the KRTA could be interpreted congruently with the federal Sherman Act. Quite the contrary, Kansas courts had on multiple occasions indicated that federal law was merely persuasive authority in interpreting Kansas antitrust law. ${ }^{239}$ To facilitate moving the litigation forward and avoid a potentially adverse ruling, the State agreed to dismiss the claims as the court requested; Kansas was one of thirteen states whose state law claims were dismissed. Kansas was able to proceed under federal law claims, and ultimately, the dismissal had no adverse impact on the outcome of the

235. Django Gold, 17 States Seek To Join E-Book Price-Fixing Suit Against Apple, LAW360 (May 11, 2012, 3:08 PM), https://www.law360.com/articles/339616/17-states-seek-to-join-e-book-price -fixing-suit-against-apple ("[T]he DOJ last month opened a civil suit against Apple and the five publishers, with Hachette, HarperCollins and Simon \& Schuster immediately reaching settlements.”); DEREK SCHMIDT, KAN. ATT'Y GEN., 2012 CONSUMER PROTECTION \& ANTITRUST DIVISION ANNUAL REPORT 10 (2013), https://ag.ks.gov/docs/default-source/documents/2012-consumer-protection -annual-report.pdf?sfvrsn=f90dc91a_6 [https://perma.cc/M437-CJ8Z] (delineating the two different actions - one in litigation and one requesting settlement approval).

236. Order for Supplemental Briefing at 1-2, Texas v. Penguin Grp. (USA) Inc., No. 1:12-cv03394 (S.D.N.Y. Apr. 29, 2013).

237. KAN. STAT. ANN. §50-163(b) (2013).

238. Id. §50-164.

239. See, e.g., O'Brien v. Leegin Creative Leather Prods., Inc. (O'Brien I), 277 P.3d 1062, 1079 (Kan. 2012) ("[F]ederal precedents interpreting, construing, and applying federal statutes have little or no precedential weight when the task is interpretation and application of a clear and dissimilar Kansas statute.”). 
litigation because all parties eventually settled.

The States reached settlement with all five publishers, ${ }^{240}$ which allowed eBook distributors to reduce the prices of their eBook titles. After entering into settlement agreements with all the defendant publishers, the States and the DOJ had a nearly three-week trial against Apple in June 2013. ${ }^{241}$ On July 10, 2013, a decision was handed down against Apple, which found that Apple had "conspired to restrain trade in violation of Section 1 of the Sherman Act and relevant state statutes to the extent those laws [were] congruent with Section 1."242 The court also entered an injunctive order-which prevented Apple from signing agreements with the publishers that restrict ability to set, alter, or reduce the price of eBooks - and required Apple to apply the same terms and conditions to eBooks sold on its devices and on other applications. ${ }^{243}$

Apple appealed the district court decision to the Second Circuit. ${ }^{244}$ The trial had been bifurcated, and the district court decision was only as to liability. While the appeal was still pending, Apple and the States entered into a rather unique "outcome determinative" settlement agreement regarding damages, which hinged on the outcome of the appeal. ${ }^{245}$ There were three possible outcomes: (1) If the liability decision was affirmed on any grounds, Apple would pay $\$ 400$ million for nationwide consumer compensation, \$20 million to the States, and \$30 million to class counsel; (2) If the liability decision was vacated and remanded or reversed and remanded with instructions for reconsideration or for retrial, Apple would pay $\$ 50$ million for nationwide consumer compensation, $\$ 10$ million to the States, and $\$ 10$ million to class counsel; and (3) If the liability decision was reversed in its entirety, Apple would pay nothing. ${ }^{246}$ Kansas agreed to the settlement because it made the most sense, both for the State and for Kansas consumers. The settlement represented substantial recovery for consumers, so long as liability was upheld, and avoided the need for a damages trial. There was, of course, a

240. See United States v. Apple Inc., 952 F. Supp. 2d 638, 645 (S.D.N.Y. 2013) (“[T] $]$ he Publisher Defendants have settled their claims with both the DOJ and the States."), aff'd, 791 F.3d 290 (2d Cir. 2015).

241. Press Release, U.S. Dep't of Justice, Department of Justice Proposes Remedy to Address Apple's Price Fixing (Aug. 2, 2013), https://www.justice.gov/opa/pr/department-justice-proposes -remedy-address-apple-s-price-fixing [https://perma.cc/2PS4-5CL9].

242. Apple Inc., 952 F. Supp. $2 \mathrm{~d}$ at 709.

243. United States v. Apple, Inc., No. 1:12-CV-2826, 2013 WL 4774755, at*2-3 (S.D.N.Y. Sept. 5, 2013).

244. See generally United States v. Apple, Inc., 791 F.3d 290 (2d Cir. 2015).

245. See Memorandum in Support of Plaintiffs' Motion for Final Approval of Apple Settlement and Distribution Plan at 4-7, Texas v. Penguin Grp. (USA) Inc., No. 12-cv-03394, 2014 WL 9963295 (S.D.N.Y. Nov. 14, 2014).

246. Id. at 5 . 
risk that the decision would be reversed and the states and consumers would be left with nothing, but we were confident in our claims and, should the decision have been reversed, nonpayment would have been the just and reasonable outcome.

Two of the publishers appealed the injunction entered by the district court because the injunction time period entered against Apple was longer than the injunction entered against the publishers. ${ }^{247}$ The publishers argued that the injunction against Apple modified the injunction against them. ${ }^{248}$ A split Second Circuit upheld the district court's decision and injunctive relief. ${ }^{249}$ Apple appealed the Second Circuit decision against it, but its petition for a writ of certiorari to the United States Supreme Court was denied. ${ }^{250}$

\section{Government and Nonprofit Investments}

In 2016, the Attorney General entered into settlements with two financial institutions ${ }^{251}$ pursuant to the same investigation of the municipal bond derivative investment industry discussed in Part III. These later settlements were reached in cooperation with private class counsel in In Re Municipal Derivatives Antitrust Litigation. ${ }^{252}$

In 2012, both the DOJ and the U.S. Commodity Futures Trading Commission settled charges against Barclays PLC, Barclays Bank PLC, and Barclays Capital Inc. for attempting to "manipulate and ma[king] false reports concerning two global benchmark interest rates," the London Interbank Offer Rate (LIBOR) and the Euro Interbank Offered Rate (Euribor). ${ }^{253}$ State and local governmental and nonprofits, as well as institutional and other private entities, use various types of financial

247. Apple, Inc., 791 F.3d at 297.

248. Id.

249. Id. at 339 .

250. United States v. Apple, Inc., 136 S. Ct. 1376 (2016).

251. These two institutions were Natixis Funding Corp. and Société Générale, S.A. See Anne Steele, Natixis, Société Générale Settle Municipal Bond Fraud Charges, Wall StreEt J. (Feb. 24, 2016, 1:39 PM), https://www.wsj.com/articles/natixis-societe-generale-settle-municipal-bond-fraud -charges-1456339181 [https://perma.cc/JJ95-9XSJ].

252. See Order, In re Municipal Derivatives Antitrust Litig., No. 08-02516 (VM), 2016 WL 11543257 (S.D.N.Y. July 8, 2016).

253. Press Release, Commodity Futures Trading Comm'n, CFTC Orders Barclays to Pay $\$ 200$ Million Penalty for Attempted Manipulation of and False Reporting Concerning LIBOR and Euribor Benchmark Interest Rates (June 27, 2012), https://www.cftc.gov/PressRoom/PressReleases/pr6289 -12 [https://perma.cc/C3YN-6XYS]; see also Press Release, U.S. Dep't of Justice, Barclays Bank PLC Admits Misconduct Related to Submissions for the London Interbank Offered Rate and the Euro Interbank Offered Rate and Agrees to Pay $\$ 160$ Million Penalty (June 27, 2012), https:// www.justice.gov/opa/pr/barclays-bank-plc-admits-misconduct-related-submissions-london-interbank -offered-rate-and [https://perma.cc/SVU3-XH32]. 
instruments in investing and other financial endeavors. Many of these financial instruments contain variable terms that are dependent upon LIBOR. ${ }^{254}$ Such instruments include, but are not limited to, interest rate swaps, collateralized debt obligations, floating rate notes, forward rate agreements, asset-backed securities, options, structured notes, and variable-rate bonds. ${ }^{255}$ The States opened an investigation. ${ }^{256}$

Between 2016 and 2018, the States negotiated and entered into settlements with Barclays Bank PLC and Barclays Capital Inc., Deutsche Bank Aktiengesellschaft, Citibank, N.A., and UBS AG. ${ }^{257}$ The agreements settled allegations related to "manipulation of certain benchmark interest rates, including but not limited to the [LIBOR] and the [Euribor], and instruments referencing those rates." 258 Identified state governmental and not-for-profit organizations affected by this manipulation received restitution payments from the settlements. ${ }^{259}$

254. See Staff Statement on LIBOR Transition, U.S. SEC. \& EXCH. COMM'N (July 12, 2019), https://www.sec.gov/news/public-statement/libor-transition [https://perma.cc/MXH7-LW56] ("LIBOR is an indicative measure of the average interest rate at which major global banks could borrow from one another."); see also London Interbank Offered Rate (LIBOR), INVESTOR.GOV, https://www.investor.gov/introduction-investing/investing-basics/glossary/london-interbank-offered -rate-libor [https://perma.cc/2GKH-89NF] (last visited Apr. 6, 2020) (referring to LIBOR as the "interest rates banks charge each other for short-term loans" and noting that "LIBOR is frequently used as the base for resetting rates on floating-rate securities").

255. See Staff Statement on LIBOR Transition, supra note 254 ("LIBOR is used extensively in the U.S. and globally as a 'benchmark' or 'reference rate' for various commercial and financial contracts, including corporate and municipal bonds and loans, floating rate mortgages, asset-backed securities, consumer loans, and interest rate swaps and other derivatives.").

256. Matthew Goldstein, Barclays Agrees to Settle Libor-Rigging Inquiry for $\$ 100$ Million, N.Y. TiMES (Aug. 8, 2016), https://www.nytimes.com/2016/08/09/business/dealbook/barclays-agrees-to -settle-libor-rigging-inquiry-for-100-million.html [https://perma.cc/7XXP-68CM] (noting that fortyfour states brought an investigation against the British bank and eventually reached a settlement).

257. DeREK SCHMidT, KAN. ATt'y Gen., 2018 CONSUMER ProteCtion \& ANTITRUST Division ANNUAL REPORT 18 (2019), https://ag.ks.gov/docs/default-source/reports/consumer/2018-consumerreport.pdf?sfvrsn=feb1d31a_4 [https://perma.cc/HZJ9-MV3V] (listing the amounts Kansas received in each settlement); see also Settlement Agreement Between States and Barclays Bank PLC and Barclays Capital Inc. (Aug. 8, 2016), https://www.njconsumeraffairs.gov/ocp/Legal\%20Filings/0808 2016-Barclays.pdf [https://perma.cc/8WR7-U597] [hereinafter Barclays Settlement Agreement]; Settlement Agreement Between States and UBS AG (Dec. 21, 2018), https://www.attorneygeneral .gov/wp-content/uploads/2018/12/2018-12-21-UBS-Settlement-Agreement-Executed.pdf [https:// perma.cc/4UD3-FSBG] [hereinafter UBS AG Settlement Agreement]; Settlement Agreement Between States and Citibank, N.A. (June 13, 2018), https://ag.ny.gov/sites/default/files/citi _settlement_agreement.pdf [https://perma.cc/ZLL2-S9JD] [hereinafter Citibank Settlement Agreement].

258. Barclays Settlement Agreement, supra note 257, at 1 (listing manipulation of both LIBOR and Euribor); UBS AG Settlement Agreement, supra note 257, at 1 (noting manipulation of LIBOR); Citibank Settlement Agreement, supra note 256, at 1 (noting manipulation of LIBOR).

259. Barclays Settlement Agreement, supra note 257, at 10 (providing the details of a $\$ 100,000,000$ settlement); UBS AG Settlement Agreement, supra note 257, at 8 (providing the details of a $\$ 68,000,000$ settlement); Citibank Settlement Agreement, supra note 257, at 8 (providing the details of a $\$ 100,000,000$ settlement); see also Press Release, Office of the Md. Att'y Gen., Attorney 


\section{Mergers}

T-Mobile announced plans to acquire Sprint in 2018. ${ }^{260}$ After investigation, the Attorney General chose to join litigation with the DOJ and then settled with the parties for divestiture of assets and build out commitments. ${ }^{261}$ This matter was of particular importance to the State of Kansas for many reasons, including that Sprint is one of the largest private employers in the state. ${ }^{262}$ The Attorney General has a unique position when it comes to enforcement because he or she must consider a myriad of factors when evaluating a merger for antitrust concerns, including the effect on Kansas consumers, the economy, and even labor markets. On April 1, 2020, the district court entered the proposed final judgment requested by the DOJ and the state attorneys general. ${ }^{263}$ The merger was also challenged by a separate group of states, in the Southern District of New York, which considered the settlement inadequate to address competitive concerns. ${ }^{264}$ The New York court refused to block the merger, finding the divestiture agreement sufficient to allay competition concerns. ${ }^{265}$

General Frosh Announces \$220 Million Settlement with Deutsche Bank for Manipulating LIBOR Interest Rate Benchmarks (Oct. 25, 2017), http://www.marylandattorneygeneral.gov/Press/2017 /102517.pdf [https://perma.cc/Q6CC-MERZ] ("Governmental and not-for-profit entities with LIBORlinked swaps and other investment contracts with Barclays (Deutsche Bank) will be notified if they are eligible to receive restitution ....").

260. T-Mobile and Sprint to Combine, Accelerating 5 G Innovation \& Increasing Competition, TMoBILE (Apr. 29, 2018), https://www.t-mobile.com/news/5gforall [https://perma.cc/D9ME-X2GS].

261. United States v. Deutsche Telekom AG, No. 1:19-cv-02232 (D.D.C. filed July 26, 2019); Proposed Final Judgment and Competitive Impact Statement, United States v. Deutsche Telekom AG, 84 Fed. Reg. 39,862, 39,863 (Aug. 12, 2019) ("On July 26, 2019, the United States, together with the State of Kansas, State of Nebraska, State of Ohio, State of Oklahoma and the State of South Dakota, filed a Complaint alleging that the proposed acquisition of Sprint Corp. by T-Mobile US, Inc. would violate Section 7 of the Clayton Act, 15 U.S.C. 18.").

262. Top Employers, KAN. DEP'T OF COMMERCE, https://www.kansascommerce.gov/the-kansas -edge/learn-about-kansas/top-employers/ [https://perma.cc/VYG9-XMJQ] (last visited Apr. 6, 2020) (listing Sprint as the third largest employer in Kansas).

263. United States v. Deutsche Telekom AG, No. 1:19-cv-02232-TJK (D.D.C. Apr. 1, 2020); Press Release, U.S. Dep't of Justice, Court Enters Final Judgment in T-Mobile/Sprint Transaction (Apr. 1, 2020), https://www.justice.gov/opa/pr/court-enters-final-judgment-t-mobilesprint-transaction [https://perma.cc/TCC2-HCS2].

264. Complaint at 2, 4-5, New York v. Deutsche Telekom AG, No. 1:19-cv-05434 (S.D.N.Y. June 11, 2019)

265. New York v. Deutsche Telekom AG, No. 1:19-cv-05434, 2020 WL 635499 (S.D.N.Y. Feb. 11, 2020); Matthew Perlman, T-Mobile, Sprint Beat State-Led Merger Challenge, LAW360 (Feb. 11, 2020, 8:54 AM), https://www.law360.com/articles/1242797/t-mobile-sprint-beat-state-led-merger -challenge. 


\section{Technological Services}

Many consider the technology industry the "next frontier" of antitrust enforcement. ${ }^{266}$ Big players include Google, Facebook, and other large providers of internet based services. ${ }^{267}$ Although it is unusual for the Attorney General to announce an investigation, Kansas, along with other investigating states, has taken the unusual step of announcing its participation in investigations in this area due to "heightened public scrutiny and policy discussions surrounding the business practices" of major technology companies. $^{268}$ Allegations surrounding big tech companies include putting consumer data at risk, reducing consumer choice, increasing the price of advertising, blocking access to platforms, and other anticompetitive behaviors. ${ }^{269}$ Because these matters are currently under confidential investigation, no more can be said specifically about them.

\section{B. Private Kansas Antitrust Litigation: 2013-2019}

\section{Kansas Court of Appeals Decisions}

The Kansas Supreme Court has not issued a KRTA opinion since the 2013 amendments were enacted. ${ }^{270}$ Three cases have been decided by the Kansas Court of Appeals since 2013, but only one was designated for publication, Smith v. Philip Morris Cos. ${ }^{271}$ That matter was decided after

266. See, e.g., David Smith, A New Antitrust Frontier-The Issue Closing Partisan Divides in the Name of Policing Big Tech, THE GuARDIAN (Feb. 3 2019, 1:00 PM), https://www.theguardian .com/us-news/2019/feb/02/a-new-antitrust-frontier-the-issue-closing-partisan-divides-in-the-name-of -policing-big-tech [https://perma.cc/J6AR-MA9V]; Jack Nicas et al., How Each Big Tech Company May Be Targeted by Regulators, N.Y. TIMES (Sept. 8, 2019), https://www.nytimes.com/2019/09/08 /technology/antitrust-amazon-apple-facebook-google.html [https://perma.cc/QAQ4-2WP4].

267. Nicas et al., supra note 266.

268. Press Release, Derek Schmidt, Kan. Att'y Gen., AG Derek Schmidt: Kansas Part of Multistate Investigation into Google Business Practices (Sept. 9, 2019), https://ag.ks.gov /media-center/news-releases/2019/09/09/ag-derek-schmidt-kansas-part-of-multistate-investigationinto-google-business-practices [https://perma.cc/SR7J-DPML].

269. Press Release, Letitia James, N.Y. Att'y Gen., Attorney General James Gives Update On Facebook Antitrust Investigation (Oct. 22, 2019), https://ag.ny.gov/press-release/2019/attorney -general-james-gives-update-facebook-antitrust-investigation [https://perma.cc/C9N8-G5KP]; Press Release, Ken Paxton, Tex. Att'y Gen., Attorney General Paxton Leads 50 Attorneys General in Google Multistate Bipartisan Antitrust Investigation (Sept. 9, 2019), https://www.texasattorneygeneral.gov /news/releases/attorney-general-paxton-leads-50-attorneys-general-google-multistate-bipartisan-anti trust [https://perma.cc/CUZ5-8EGQ].

270. The last Kansas Supreme Court opinion regarding the KRTA was issued on August 31, 2012. Seaboard Corp. v. Marsh Inc., 284 P.3d 314, 317 (Kan. 2012).

271. 335 P.3d 644 (Kan. Ct. App. 2014); O’Brien v. Leegin Creative Leather Prods., Inc. (O’Brien II), No. 108,988, 2014 WL 1362657 (Kan. Ct. App. Apr. 4, 2014); Idstrom v. All. Radiology, P.A., No. 115,099, 2017 WL 129926 (Kan. Ct. App. Jan. 13, 2017). 
the 2013 legislative change; however, the original complaint was filed prior to the statute change, which did not apply retroactively to cases already pending. ${ }^{272}$ Therefore, the court ruled on the matter pursuant to the 2000 version of the KRTA, finding that federal antitrust law interpretations can be persuasive authority, but only to the extent they "do not conflict with clearly dissimilar provisions in the KRTA."273

The Smith case was brought as a class action on behalf of Kansas retailers, alleging a conspiracy among tobacco manufacturers to "fix the wholesale price of cigarettes in violation of the Kansas Restraint of Trade Act." ${ }^{274}$ The defendants won summary judgment at the lower court. ${ }^{275}$ One of the key issues on appeal was a legal theory that had never been discussed by Kansas courts: conscious parallelism. ${ }^{276}$ Conscious parallelism can emerge in any market with a limited number of players and is not in and of itself unlawful. ${ }^{277}$ It happens when companies in a market set their prices at the same, often supracompetitive, level in a "consciously parallel fashion." 278 The companies might be mutually aware of their parallel pricing but if the decision is made independently, it is legal. ${ }^{279}$ The situation can become illegal if the companies come to an agreement or understanding to fix prices. ${ }^{280}$ When, as in this case, evidence of conscious parallelism is present, courts must ensure that lawful, unilateral conduct is not punished-something more is required. ${ }^{281}$ The appellate court noted that the Kansas Supreme Court, in O'Brien I, found the KRTA demanded "something more than merely a unilateral pricing policy." 282 In this instance, federal and state law share language, "between persons," so the Kansas Supreme Court looks to "United States Supreme Court precedent for assistance."283 The Smith court found that requiring the plaintiff to show more than unilateral pricing activity-plus factors - to withstand summary judgment was consistent with state law. ${ }^{284}$

272. KAN. Stat. ANN. § 50-164 (2013); Smith, 335 P.3d at 652-53.

273. Smith, 335 P.3d at 653.

274. Id. at 650 .

275. Id. at $650-51$.

276. $I d$. at $663-64$.

277. Id. (quoting In re Baby Food Antitrust Litig., 166 F.3d 112, 121-22 (3d Cir. 1999)).

278. Id.

279. Id.

280. Id. at 664 .

281. Id. at 664,666 ("[R]easonable minds cannot infer that price-fixing is afoot merely from conscious parallel pricing conduct of oligopolists. Something more must be shown to establish a reasonable inference that such competitors acted in concert." (emphasis added)).

282. Id. at 665 (quoting O'Brien v. Leegin Creative Leather Prods., Inc. (O'Brien I), 277 P.3d 1062, 1087 (Kan. 2012)).

283. Id.

284. Id. at 666 . 
The Idstrom case, decided in 2017, involved a dispute by a terminated shareholder against his medical group and former partners. ${ }^{285}$ The plaintiff had multiple allegations of wrongdoing, including a violation of the KRTA. The jury in the district court found the medical group had not violated the KRTA but that his partners had breached fiduciary duties owed to him. ${ }^{286}$ Although the jury found there was a civil conspiracy, it found that the medical group was not a trust pursuant to the KRTA. ${ }^{287}$ The court found that plaintiff was required to prove that the medical group was a trust before he could recover damages from the shareholders pursuant to the KRTA. ${ }^{288}$

The O'Brien I decision was appealed a second time in 2014; this time to the Kansas Court of Appeals (O'Brien II). ${ }^{289}$ The court commented on whether the KRTA applies retroactively and O'Brien I's precedential value:

In direct response to the Kansas Supreme Court's earlier decision in this case, the Kansas Legislature made significant amendments to the Kansas Restraint of Trade Act, effective April 18, 2013 ... . [T]he legislature declared that its new provision allowing reasonable restraint of trade should apply retroactively except for cases, like this one, that were pending before April 18, 2013.

The end result is that most of O'Brien's precedential value is limited to this case and any other case that was already pending before April 18, 2013. Accordingly, our opinion in this case will have very limited precedential value going forward regarding issues arising under the Kansas Restraint of Trade Act. . . . ${ }^{290}$

The issue on appeal was the lower court's decision to modify the class, which the Kansas Court of Appeals reversed and remanded, finding the lower court had failed to perform a rigorous analysis of class certification factors or to acknowledge that more than one antitrust statute provided a basis for class recovery. ${ }^{291}$ Because, as the court clearly acknowledged, the statutes examined in the opinion were repealed by the 2013 amendment, we will not delve into the case further. ${ }^{292}$

285. Idstrom v. All. Radiology, P.A., No. 115,099, 2017 WL 129926, at*1 (Kan. Ct. App. Jan. $13,2017)$.

286. Id.

287. Id. at *9-10.

288. Id.

289. O'Brien v. Leegin Creative Leather Prods., Inc. (O'Brien II), No. 108,988, 2014 WL 1362657

(Kan. Ct. App. Apr. 4, 2014).

290. Id. at *5 (citations omitted).

291. Id. at *13.

292. Id. at *5; S.B. 124, 85th Leg., Reg. Sess. (Kan. 2013). 


\section{U.S. Supreme Court Decisions}

Only one United States Supreme Court case has addressed the KRTA in the past twenty years, Oneok, Inc. v. Learjet, Inc. ${ }^{293}$ Although there is not a detailed discussion of Kansas law specifically, the finding of the Court affirmed that Kansas antitrust law was not preempted by the federal Natural Gas Act. ${ }^{294}$ A group of end-user purchasers in several states bought natural gas directly from interstate pipelines. ${ }^{295}$ They brought state and federal lawsuits suing those pipelines over claims that they had engaged in anticompetitive conduct that caused them to pay higher prices. ${ }^{296}$ The conduct engaged in affected both wholesale and resale pricing. ${ }^{297}$ The state lawsuits were removed to federal district court and consolidated. ${ }^{298}$ The district court found that the purchasers' claims were preempted by the Natural Gas Act. ${ }^{299}$ The purchasers appealed to the Ninth Circuit which reversed the decision. ${ }^{300}$ The Ninth Circuit interpreted the "Natural Gas Act's pre-emptive scope narrowly in light of Congress' intent-manifested in $\S 1$ (b) of the Act - to preserve for the States the authority to regulate non-jurisdictional sales."301

The pipelines then appealed to the Supreme Court. The State of Kansas drafted and filed an amicus brief, which twenty other state attorneys general joined, arguing that the Supreme Court should respect the "dual federal and state regulation that Congress has carefully respected and preserved in this context" and affirm the Ninth Circuit holding. ${ }^{302}$ The amicus brief reaffirmed that state antitrust powers are within the traditional police powers of the States and federal acts do not displace them absent actual conflict between the two. ${ }^{303}$ In this matter, Congress "was meticulous to take in only territory which this Court had held the States could not reach." "304 Thus, the States argued the Court should "maintain and continue to enforce the longstanding line" both the Natural Gas Act

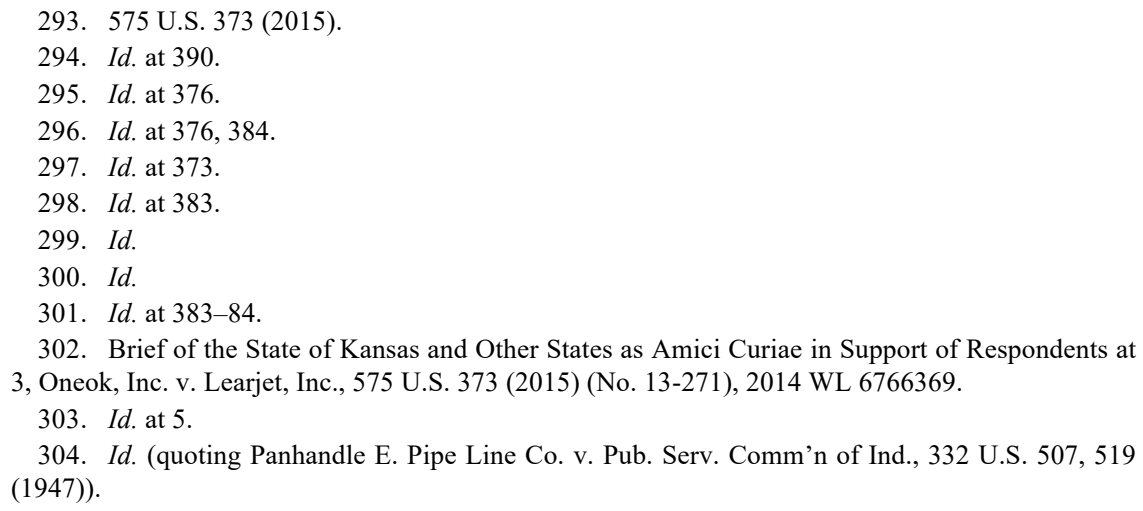


itself and the Court had "recognized between federal and state regulatory power." ${ }^{305}$ The Kansas Attorney General's Office was granted ten minutes to defend this position at oral argument on January $12,2015 .^{306}$

The majority found that the Court had repeatedly stressed that the Natural Gas Act "was drawn with meticulous regard for the continued exercise of state power, not to handicap or dilute it in any way." 307 The Court ruled that the aim of state regulation determined whether it was preempted rather than the effect, and antitrust laws are not aimed at any particular company, but "all businesses in the marketplace."308 Because of the broad applicability of state antitrust law, the Court determined that no preemption should be found. ${ }^{309}$

\section{Tenth Circuit Decision}

Suture Express, Inc. v. Owens \& Minor Distribution, Inc., the only Tenth Circuit case to consider the KRTA in the past nineteen years, involved allegations of illegal tying arrangements under both federal antitrust law and the KRTA. ${ }^{310}$ The district court granted summary judgment in favor of the defendants, and the Tenth Circuit affirmed. ${ }^{311}$ The KRTA is discussed in a small subsection, with the remainder devoted to discussion of federal antitrust law. The court observed that (1) Kansas law is not the same as its federal counterparts, and (2) though it was originally enacted over a century ago, the KRTA "remains largely undeveloped." 312 The court found the plaintiff failed to carry its burden of proving a viable antitrust injury or to show that defendants intended to prevent full and free competition. ${ }^{313}$ The court undertook no discussion of the 2013 legislative amendment of the KRTA. ${ }^{314}$

\footnotetext{
305. Id. at $16-17$.

306. Oneok, Inc. et al. v. Learjet, Inc. et al.: Oral Argument - January 12, 2015, OYEZ, https://www.oyez.org/cases/2014/13-271 [https://perma.cc/5KDJ-GBHH] (last visited Apr. 12, 2020) (select "Oral Argument - January 12, 2015" under "Oral Argument").

307. Oneok, 573 U.S. at 384-85 (quoting Panhandle, 332 U.S. at 517-18).

308. Id. at 387 .

309. Id. at 389-90.

310. 851 F.3d 1029, 1036-37 (10th Cir. 2017). One other Tenth Circuit case mentions the KRTA; however, the court noted that the party abandoned the claim and there was no further discussion of the Act. Pepsi-Cola Bottling Co. of Pittsburg, Inc. v. PepsiCo, Inc., 431 F.3d 1241, 1255 n.6 (10th Cir. 2005), amended on reh'g in part (Apr. 11, 2006).

311. Suture Express, 851 F.3d at 1033-34.

312. Id. at 1046 (quoting O’Brien v. Leegin Creative Leather Prods., Inc. (O'Brien I), 277 P.3d 1062, 1068 (Kan. 2012)).

313. Id.

314. The original complaint in this action was filed on December 5,2012, prior to amendment of the KRTA. See Complaint, Suture Express, Inc. v. Cardinal Health, Inc., 963 F. Supp. 2d 1212 (D. Kan. 2012) (No. 12 Civ. 2760 RDR/KGS), 2012 WL 6049685.
} 


\section{District of Kansas Decisions}

The Federal District of Kansas has considered by far the most KRTA cases since the 2013 amendment of the KRTA. The most recently decided District of Kansas case, Reorganized FLI, Inc. v. Williams Cos., dealt with the retroactivity of the 2013 amendment to the KRTA damages provisions. ${ }^{315}$ The plaintiff filed suit in 2005 seeking full consideration damages, or a full refund of its natural gas purchases, under K.S.A. § 50115 , a statute that was repealed in $2013 .{ }^{316}$ The court noted that although the legislature enacted a savings statute that states "non-remedial provisions ... shall be applied prospectively," it does not explicitly address K.S.A. $\S 50-115 .^{317}$ However, the court acknowledged the $O$ 'Brien I court's conclusion that "if a party's cause of action arose under [K.S.A.] $\S 50-112$, the relief came from [K.S.A.] § [50]-115." 318 Therefore, to apply the statutory change retroactively would eliminate the plaintiff's damages and thus its cause of action, which would be contrary to the savings statute. ${ }^{319}$

The court also discussed two Kansas Court of Appeals decisions, $O$ 'Brien II and Smith, which both made broad statements that the KRTA amendments do not apply to cases that were pending at the time the amendments were enacted. ${ }^{320}$ Neither case specifically addresses the retroactivity of $\S 50-115$. In O'Brien II, the Kansas Court of Appeals noted the changes in the KRTA, and that those changes were enacted in direct response to the Kansas Supreme Court's earlier opinion in the case. ${ }^{321}$ The court noted the repeal of full consideration damages as well as other changes to the KRTA. ${ }^{322}$ The Kansas Court of Appeals noted that most of the precedential value from its opinion and the Kansas Supreme Court's earlier O'Brien I decision was limited to cases already pending prior to April 18, 2013. ${ }^{323}$

The O'Brien II court considered and discussed whether the district

315. Reorganized FLI, Inc. v. Williams Cos., 410 F. Supp. 3d 1213, 1216 (D. Kan. 2019), reconsideration denied, motion to certify appeal granted, No. 05-CV-02389, 2019 WL 6998756 (D. Kan. Dec. 20, 2019).

316. Id.

317. Id. at 1219

318. Id. at 1221 (citing O’Brien v. Leegin Creative Prods., Inc. (O'Brien I), 277 P.3d 1062, 1074 (Kan. 2012)).

319. Id.

320. Id. at 1219-20 (citing O'Brien v. Leegin Creative Leather Prods., Inc. (O'Brien II), No. 108,988, 2014 WL 1362657 (Kan. Ct. App. Apr. 4, 2014); Smith v. Phillip Morris Cos., 335 P.3d 644 (Kan. Ct. App. 2014)).

321. O'Brien II, $2014 \mathrm{WL} 1362657$, at *5.

322. Id.

323. Id. 
court improperly modified the class by excluding class members. ${ }^{324}$ In making this decision, the Kansas Court of Appeals discussed legal propositions based on K.S.A. $\S 50-115$ and K.S.A $\S 50-108$, two of the three damages provisions in the KRTA. ${ }^{325}$ Although the court did not discuss whether full consideration damages under K.S.A. $\S 50-115$ remained applicable in cases that were pending at the time of the KRTA amendments, the Kansas Court of Appeals' decision implied that a claim under K.S.A. § 50-115 was still viable. ${ }^{326}$

In Smith v. Philip Morris Cos., the Kansas Court of Appeals noted that the Kansas legislature made substantial changes to the KRTA in 2013. ${ }^{327}$ The court noted the effective date of those changes but also specifically stated that they "do not apply retroactively to cases, like this one, already pending at the time." 328 The Kansas Court of Appeals stated that the legislature repealed the full consideration damages. ${ }^{329}$ The court also stated that the plaintiffs claimed full consideration damages and that it would proceed under the previous version of the KRTA because the case was pending at the time of the amendments. ${ }^{330}$ The court did not explicitly state that full consideration damages were no longer available. After reviewing O'Brien II and Smith in depth and negating out-of-state decisions and a district court decision that preceded these Kansas Court of Appeals cases, the court in Reorganized FLI found the savings statute does not clearly provide that the repeal of K.S.A. $\S 50-115$ should be applied retroactively and denied the defendants' motion for summary judgment. ${ }^{331}$

In re EpiPen was a class action alleging violations of federal law, including the Racketeer Influenced and Corrupt Organizations Act (RICO), state antitrust laws, state consumer protection laws, and unjust enrichment against the manufacturer and seller of epinephrine autoinjector devices. ${ }^{332}$ The majority of the decision discusses federal law issues and then specifically addresses alleged deficiencies in state law pleadings. The KRTA claims were dismissed because the KRTA does not recognize unilateral conduct claims; a combination or conspiracy is

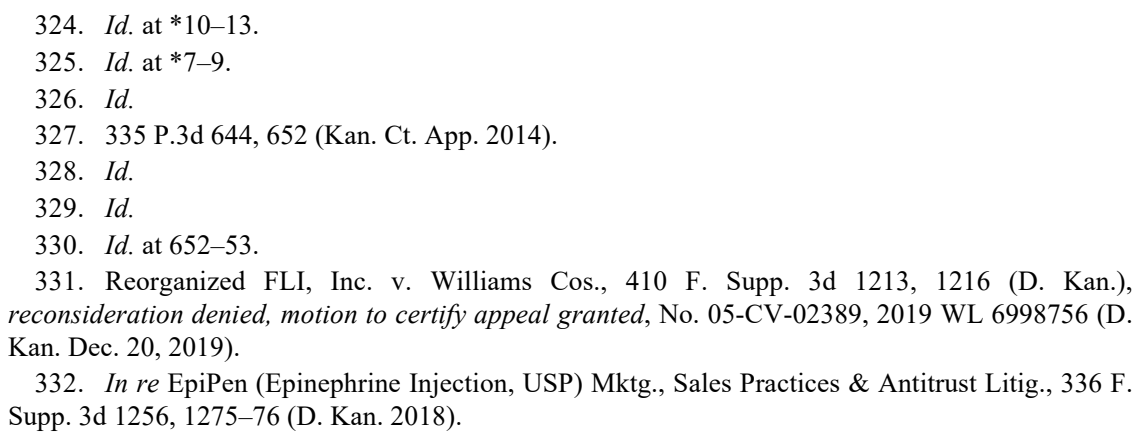


required. 333

In the Digital Ally, Inc. v. Taser International, Inc., the plaintiff accused the defendant of bribing municipalities to purchase law enforcement body cameras, denying it market access in violation of federal and state antitrust law. ${ }^{334}$ The defendant claimed it was entitled to federal Noerr-Pennington immunity and the court agreed, granting its motion to dismiss. ${ }^{335}$ Because the KRTA is to "be construed in harmony with ruling judicial interpretations of federal antitrust law by the United States Supreme Court," the court found its federal law decision was dispositive to the Kansas claims as well. ${ }^{336}$

Another District of Kansas decision discussing the KRTA is a decision which was appealed to the Tenth Circuit, Suture Express, Inc. v. Owens \& Minor Distribution, Inc. ${ }^{337}$ Suture Express alleged the defendants engaged in "tying and bundling the sale of suture and endomechanical" products to the sale of other medical-surgical distribution products. ${ }^{338}$ Both parties moved for summary judgment. ${ }^{339}$ The court acknowledged that while the KRTA and federal antitrust laws are similar, they are not the same. ${ }^{340}$ Relying on the O'Brien I decision, the court found it could not simply apply its federal analysis to the Kansas claim, but had to begin its analysis with antitrust injury. ${ }^{341}$ The court undertook a careful reading of $O^{\prime}$ Brien $I$ and found that in light of declining prices and markets, the plaintiff could not prove antitrust injury or damages causation. ${ }^{342}$ The court also found

333. Id. at $1313-14$

334. No. 16-2032, 2017 WL 131595, at*1 (D. Kan. Jan. 12, 2017), aff'd, 720 F. App'x 1023 (Fed. Cir. 2018), cert. denied, 139 S. Ct. 231 (2018).

335. Id. The Noerr-Pennington Doctrine is based on a U.S. Supreme Court case, City of Columbia v. Omni Outdoor Advertising, Inc., which held that "federal antitrust laws do not regulate the conduct of private individuals in seeking anticompetitive action from the government." 499 U.S. 365, 379-80 (1991). This doctrine "exempts from antitrust liability any legitimate use of the political process by private individuals, even if their intent is to eliminate competition." Digital Ally, Inc., 2017 WL 131595, at *1 (quoting Zimomra v. Alamo Rent-A-Car, Inc., 111 F.3d 1495, 1503 (10th Cir. 1997)).

336. Digital Ally, Inc., 2017 WL 131595, at *2 (citing KAN. STAT. ANN. § 50-163(b) (2013)).

337. No. 12-2760, 2016 WL 1377342 (D. Kan. Apr. 7, 2016), aff'd, 851 F.3d 1029 (10th Cir. 2017). The plaintiff previously survived a motion to dismiss its KRTA claims. Suture Express, Inc. v. Cardinal Health 200, LLC, 963 F. Supp. 2d 1212, 1231 (D. Kan. 2013). The court found, inter alia, that the plaintiff had stated a sufficient KRTA claim to withstand dismissing because:

[T] he general rule [in Kansas] appears to be that a complaint need not point to the appropriate statute or law in order to raise a claim for relief; a complaint may sufficiently raise a claim even if it points to no legal theory or even if it points to the wrong legal theory as a basis for that claim.

Id. at 1229 (citations omitted).

338. Suture Express, 2016 WL 1377342, at*1.

339. Id.

340. Id. at $* 33$.

341. Id. at *33-34.

342. Id. at *33-35. 
that the plaintiff couldn't prove that the contracts were intended to prevent competition. ${ }^{343}$

Finally, in Catron v. Colt Energy, Inc., Catron brought a class action in state court, alleging mineral leasing companies were allocating markets instead of competing. ${ }^{344}$ The defendants removed the case to federal court, pursuant to the Class Action Fairness Act, ${ }^{345}$ and then moved to dismiss. ${ }^{346}$ The court found that Catron had sufficiently pled a KRTA violation, ${ }^{347}$ but that he could not recover full consideration damages under the plain language of the statute which specifically discussed a remedy for buyers who had paid a sum; the plaintiff was a lessor, who was paid for the use of his property. ${ }^{348}$ Therefore, he could not recover full consideration damages. ${ }^{349}$ Other claims survived and the case was later remanded to state court. ${ }^{350}$

\section{A CONTINUED Role FOR STATE ANTITRUST IN THE 21ST CENTURY}

Some might question the need for state antitrust laws when there are federal laws, or the need for Attorney General enforcement when there are private actions, but there are many reasons Kansas antitrust law and actions by the Kansas Attorney General are important. For example, Kansas antitrust law specifically protects Kansans. While many antitrust issues in today's global society have a national or international effect, some anticompetitive actions are still limited to a small geographic area. Or, even if it has a broad effect, the action may have a particularly detrimental effect on a small localized area. That is where Kansas antitrust law, as well as the enforcement authority of the Kansas Attorney General, are particularly important. Even in multistate cases brought in federal court, Kansas legal authority and the involvement of the Kansas Attorney General ensure that the interests of Kansas citizens and the State of Kansas are protected.

\footnotetext{
343. Id. at *35.

344. No. 13-4073, 2014 WL 7246804, at*1 (D. Kan. Dec. 17, 2014).

345. 28 U.S.C. $§ 1332(d)(2)$ (2012); Catron, 2014 WL 7246804, at *1.

346. Catron, 2014 WL 7246804 , at *1.

347. $I d$. at $* 3$.

348. Id. at $* 4$.

349. Id. Catron sought full consideration damages under KAN. STAT. ANN. § 50-115 (2000), which was repealed in its entirety in 2013. S.B. 124, 85th Leg., Reg. Sess. (Kan. 2013).

350. Catron v. Colt Energy, Inc., No. 13-4073, 2015 WL 3967007, at*2 (D. Kan. June 30, 2015).
} 


\section{A. Not Preempted by Federal Law}

The Supremacy Clause of the Constitution provides that federal law is the "supreme Law of the Land," 351 And the Tenth Amendment designates that "powers not delegated to the United States by the Constitution, nor prohibited by it to the States, are reserved to the States respectively, or to the people." 352 State antitrust laws are not preempted by federal antitrust laws. Rather "Congress intended the federal antitrust laws to supplement, not displace, state antitrust remedies." 353 State antitrust laws have also been upheld in the face of other federal enforcement. One example is the U.S. Supreme Court case Oneok v. Learjet discussed previously. ${ }^{354}$ One of the arguments made by the State in its amicus filing was that the harmonization requirement in the KRTA and other states' antitrust laws is evidence that state antitrust laws are consistent with the goals and purposes of federal antitrust laws. ${ }^{355}$ In Oneok, the Court affirmed that "[s]tates have a long history of providing common-law and statutory remedies against monopolies and unfair business practices" and have a "longrecognized power to regulate combinations in restraint of trade."356

\section{B. The Attorney General's Role in Antitrust Enforcement}

The Attorney General continues to have an important and unique role in Kansas antitrust enforcement. The Attorney General has a duty to enforce the KRTA and is given authority to seek damages on behalf of state and municipal entities ${ }^{357}$ as well as the harmed members of the public. ${ }^{358}$ The statutes and case law grant the Attorney General special enforcement privileges unavailable to private litigants, and the Attorney General has the right to sue on behalf of the general public for the common welfare of Kansas. ${ }^{359}$ Attorney General enforcement of the KRTA results in a general benefit reaped by the public due to this special authority. The Attorney General also has a statutory duty to enforce the KRTA, ${ }^{360}$ which

\footnotetext{
351. U.S. CONST. art. VI, cl. 2.

352. Id. amend. X.

353. California v. ARC Am. Corp., 490 U.S. 93, 102 (1989) (citing 21 Cong. Rec. 2457 (1890) (remarks of Senator Sherman)).

354. See supra notes 293-309 and accompanying text.

355. Brief of the State of Kansas and Other States as Amici Curiae in Support of Respondents at 16, Oneok, Inc. v. Learjet, Inc., 575 U.S. 373 (2015) (No. 13-271), 2014 WL 6766369, at*16.

356. Oneok, Inc., 575 U.S. at 388 (internal quotation marks and citations omitted).

357. KAN. STAT. ANN. § 50-162 (2013).

358. Id. §50-103(a)(8).

359. Id. $\S 50-162$.

360. Id. §50-109(a).
} 
he or she accomplishes in part by investigating allegations of wrongdoing, educating the public, and filing lawsuits, comments, and amicus briefs as needed.

\section{Statute of Limitations}

A private litigant suing under the KRTA is subject to a three-year statute of limitations on claims for damages. ${ }^{361}$ In contrast, an action brought by the Attorney General, in his or her official capacity and exercising statutory authority conferred upon him or her is not subject to a statute of limitations because he or she is performing a governmental function. ${ }^{362}$ The Attorney General therefore is not bound to the three-year statute of limitation that binds private litigants and can take action against statutory violators regardless of when the violation occurred. While a private litigant is allowed to act as a "private attorney[] general" in enforcing the statute on their own behalf, "the Attorney General is explicitly empowered to seek civil penalties to punish a violation on behalf of the rest of the citizens of the state." 363

\section{Harm to the State}

The Attorney General is uniquely situated to bring claims for harm on behalf of the State, its agencies and political subdivisions - both by a specific grant of authority in the KRTA ${ }^{364}$ and in his or her position as the chief law enforcement officer of the State. ${ }^{365}$ The Attorney General can institute an action "on behalf of the State of Kansas or of any city, town, or political subdivision, or other governmental agency, body or authority established under the law of the state of Kansas," and can also intervene in any action or proceeding on behalf of the same. ${ }^{366}$ It is typically far more efficient for the Attorney General to act on behalf of affected governmental entities in one proceeding than for multiple actions to proceed, which may result in differing, contradictory rulings.

361. Seaboard Corp. v. Marsh Inc., 284 P.3d 314, 317 (Kan. 2012) (citing KAN. STAT. ANN. § 60$512(2))$.

362. See State ex rel. Stephan v. Brotherhood Bank \& Tr. Co., 649 P.2d 419, 423-24 (Kan. 1982).

363. O'Brien v. Leegin Creative Leather Prods., Inc. (O'Brien I), 277 P.3d 1062, 1086 (Kan. 2012) (citing KAN. STAT. ANN. \$§ 50-103(a)(5), -160).

364. KAN. STAT. ANN. § 50-162.

365. Id. § 75-764(a); see also id. § 75-702 (2013) ("The attorney general shall appear for the state, and prosecute and defend any and all actions and proceedings, civil or criminal, in the Kansas supreme court, the Kansas court of appeals and in all federal courts, in which the state shall be interested or a party, and shall, when so appearing, control the state's prosecution or defense.").

366. Id. § 50-162. 


\section{Citizens and Parens Patriae}

The Attorney General also has authority to bring actions to recover on behalf of the State's citizens. It is one of the enumerated powers of the Attorney General under the KRTA. ${ }^{367}$ At least one court has described this grant of authority as the functional equivalent of a related authority known as parens patriae, which allows the Attorney General to bring claims on behalf of Kansas citizens. ${ }^{368}$ In Kansas cases, parens patriae is most commonly discussed in relation to juvenile offenses, child custody, and state commitments. Given that "parens patriae" literally translates as "parent of the country" 369 this should come as no surprise. In the antitrust and similar legal contexts where the rights of citizens are affected, parens patriae is a quasi-sovereign interest that is asserted by the State on behalf of its citizens. ${ }^{370}$ The Attorney General is the only party authorized to bring a parens patriae claim on behalf of the State and its citizens ${ }^{371}$ and such claims can be asserted under both state and federal law. ${ }^{372}$ The U.S. Supreme Court has found that States have a constitutional power ${ }^{373}$ to bring parens lawsuits.

\section{CONCLUSION}

Kansas has a rich antitrust history, dating back over a century, which continues to develop today as we enter the third decade of the twenty-first century. The Kansas antitrust laws began with much vigor and movement, then little major amendment occurred from 1923 to 2000. Following that, the KRTA was amended twice in thirteen years. It remains to be seen

367. Id. §50-103(a)(8).

368. In re Lorazepam \& Clorazepate Antitrust Litig., 205 F.R.D. 369, 386 (D.D.C. 2002) (citing KAN. STAT. ANN. § 50-103(a)(8)).

369. Alfred L. Snapp \& Son, Inc. v. Puerto Rico ex rel. Barez, 458 U.S. 592, 600 (1982) (citation omitted).

370. Id. at 607; see also Romualdo P. Eclavea, Annotation, State's Standing to Sue on Behalf of Its Citizens, 42 A.L.R. Fed. $23 \S 2$ (a) (1979) ("[A] state has standing to maintain on behalf of its citizens suits seeking injunctive relief against: the diversion of, or interference with, the waters from a river or lake....").

371. In re Packaged Seafood Prods. Antitrust Litig., 338 F. Supp. 3d 1079, 1101 (S.D. Cal. 2018) ("Kansas law allows the Kansas attorney general to bring a representative action," but it does not allow a foreign sovereign many not bring an action as parens patriae (citations omitted)).

372. Kansas ex rel. Hayden v. United States, 748 F. Supp. 797, 802 (D. Kan. 1990) ("Under the modern-day doctrine of parens patriae, the concept of standing has been broadened to recognize that an injury may be suffered by a state when the statutory provisions of a federal act are violated." (citation omitted)), on reconsideration, 751 F. Supp. 1495 (D. Kan. 1990), aff'd, 953 F.2d 1392 (10th Cir. 1992).

373. Hawaii v. Standard Oil Co., 405 U.S. 251, 258-59 (1972) (noting that case law establishes "the right of a State to sue as parens patriae to prevent or repair harm to its 'quasi-sovereign' interests ... pursuant to Art. III, § 2, of the Constitution under common-law rights of action"). 
whether the KRTA will remain in its current form for another eighty years or if further legislative action will occur. What we know for sure is the Attorney General, the private litigant, the legislature, and the courts all have important roles to play in shaping the development and trajectory of antitrust enforcement in the years to come. 